Technological University Dublin

DƯBLIN

ARROW@TU Dublin

2007-06-11

\title{
International Transmission Effects of Volatility Between Financial Markets in the G-7 since the Introduction of the Euro
}

Lucia Morales

Technological University Dublin, lucia.morales@tudublin.ie

Follow this and additional works at: https://arrow.tudublin.ie/buschaccon

Part of the Finance and Financial Management Commons

\section{Recommended Citation}

Morales, L.: International transmission effects of volatility between financial markets in the G-7 since the introduction of the euro. INFINITI Conference on International Finance, Trinity College Dublin, 11-12 June, 2007.

This Conference Paper is brought to you for free and open access by the School of Accounting and Finance at ARROW@TU Dublin. It has been accepted for inclusion in Conference papers by an authorized administrator of ARROW@TU Dublin. For more information, please contact arrow.admin@tudublin.ie, aisling.coyne@tudublin.ie,gerard.connolly@tudublin.ie. 


\title{
International Transmission Effects of Volatility between Financial Markets in the G-7 since the introduction of the Euro
}

\begin{abstract}
This paper investigates the nature of volatility spillovers between stock returns and a number of exchange rates changes for the G-7 countries for the 1996-2006 period. We divide our sample into a number of sub periods, prior to and after the introduction of the Euro, we use EGARCH modelling which takes into account whether bad news has the same impact on volatility as good news. Our results show that in terms of volatility spillover effects from stock returns to exchange rates returns, there is a large degree of consistency across counties and time periods with significant spillovers found for all countries, in all three periods, with the exception of Italy in the pre-Euro period. The impact of stock market volatility on exchange rates thus does not appear to have been altered significantly by the introduction of the Euro in the sense that the cross exchange rates against the $\$$, Yen, $£$ and $\mathrm{CHF}$ existed prior to the introduction of the Euro as well as after it across nearly all G-7 markets In contrast, our results indicate that in terms of volatility spillovers from exchange rates to stock markets, the results are less consistent both across countries and over time but overall we find much less evidence supporting volatility spillovers from exchange rates to stock markets. There is however some commonality regarding which exchange rates we find significant volatility spillover effects to stock markets for the period after the Euro was introduced. The lack of significant spillovers from exchange rate changes to stock returns found here for some countries across a number of exchange rates is consistent with existing research in this area.
\end{abstract}

\section{Introduction}

The aim of this paper is to investigate the interdependence of stock returns and exchange rates changes for the G-7 financial markets and the main exchange rates, with the objective of identifying which currencies will generate a stronger impact in the financial markets in the G-7 before and after the introduction of the Euro. Several theoretical models have found empirical evidence that the exchange rate between two currencies is affected by stock price changes in the respective countries; for example, Zapatero (1995) shows that in fully integrated financial markets, there is an explicit linkage between the volatility of stock prices and the volatility of the exchange rate. More recently, Yang and Doong (2002) note that given the rapid integration and deregulation of international financial markets in recent years, exchange rates have become more sensitive to stock market innovations. A number of studies have investigated the extent of volatility spillovers between stock markets and exchange rates in the G7 countries (see for example, Yang and Doong, 2004; Kanas, 2000, 2002). However no study to date has specifically investigated volatility spillovers between stock markets and exchange rates in the G7 since the introduction of the Euro. In addition to this there is a lack of evidence of studies studying this issue taking into account the effect of exchange rates other than for the domestic currency on the stock returns of these countries. Therefore, we attempt to address the gap in the literature in this area by conducting a in depth analysis of the relationship between these two variables, with the objective of also adding to the general literature in this area investigating spillovers between stock markets and exchange rates for a number of exchange rates. Current evidence for the G-7 has focused exclusively on spillovers between the domestic currency and the stock market, for this reason we analyse the 
relationship between these two variables in a wider way. Section 1 sets out the theoretical and empirical evidence on the nature of linkages between stock markets and exchange rates. Section 2 describes of the methodology we use to assess the nature of volatility spillovers between the stock and foreign exchange markets, section 3 present our empirical results and we discuss our data and section 4 concludes the paper.

\section{Literature Review}

Several theoretical models have analysed the link between stock markets and currency markets. The asset market approach to exchange rate determination (Branson, 1983; Frankel, 1983) posits that causality will run from stock prices to exchange rate changes as expectations of financial asset price movements affect the dynamics of exchange rates. Smith (1992) derives an estimable equation for the exchange rate where the stock price is included as an explanatory variable. The goods market approach suggests causality runs in the opposite direction, from exchange rates to stock prices (Mundell, 1963, 1964; Dornbusch and Fisher, 1980). In these models, movements in exchange rates affect the international competitiveness of firms which affects real income and output and eventually stock prices.

Much of the available empirical evidence on the linkages between stock markets and exchange rates has concentrated on the first moments ${ }^{1}$. Yang and Doong (2004) note that there is a dearth of empirical evidence that concentrates on the linkages between the second moments of the distribution of the variables. A number of studies however have examined the extent to which volatility from one stock market spills over into other stock markets or between different assets ${ }^{2}$. Kanas (2000) was one of the first studies which analysed volatility spillovers from stock returns to exchange rate changes in the USA, the UK, Japan, Germany, France and Canada. He found evidence of spillovers from stock returns to exchange rate changes for all countries except Germany, suggesting that the asset approach to exchange rate determination is valid when formulated in terms of the second moments of the exchange rate distribution for the countries included in his analysis. Volatility spillovers from exchange rate changes to stock returns were insignificant for all countries. Assoé (2001) investigates the dynamic interrelationship between exchange rate changes and stock market performance in eleven emerging markets and five developed markets, using a trivariate Exponential-GARCH model. His results indicate that shocks in foreign exchange markets significantly increase volatility in emerging stock markets. He also found evidence of asymmetric volatility spillover from FX markets to stock markets for some of the countries that were included in his analysis. The asymmetric nature of volatility transmission suggest that investors in these markets react more to adverse innovations in foreign exchange markets than to positive shocks. Yang and Doong (2004) explored the nature of the mean and volatility transmission mechanism between stock and foreign exchange markets for the G-7 countries. The results point to significant volatility spillovers and an asymmetric effect from the stock market to the foreign exchange market for France, Italy, Japan and the US, suggesting integration between stock and foreign exchange markets in these countries. Kanas (2000) and Yang and Doong (2004) concentrate exclusively on the domestic currency and do not investigate the extent of spillovers from other currencies to the domestic stock market. Wu (2005) examines volatility spillovers between stock prices and exchange rates for Japan, South Korea, Indonesia, Philippines, Singapore, Thailand and Taiwan for the period 1997-2000, splitting the sample into crises and recovery periods. He found a bi-directional relationship between the volatility of stock returns and exchange rate changes during the recovery period in all countries except South Korea, as well as significant contemporaneous relationships between the two markets for most of the countries. Furthermore, he found volatility spillovers

\footnotetext{
${ }^{1}$ See for example Nieh and Lee (2001), Yau and Nieh (2006) for recent evidence on this topic.

${ }^{2}$ See also for example, Nelson (1991), Koutmos and Booth (1995), Laopodis (1998).
} 
increased in the recovery period. Qayyum and Kemal (2006) examine volatility spillover between the stock market and the foreign exchange market in Pakistan, through a bivariate EGARCH model. Their results show that the behaviour of both the stock exchange and the foreign exchange markets are interlinked. The returns of one market are affected by the volatility of the other market. In particular the returns of the stock market are sensitive to the returns as well as the volatility of foreign exchange markets. They found evidence of strong relationship between the volatility of foreign exchange market and the volatility of returns in stock market. Leeves (2007) analyse the conditional volatility in stock returns in Indonesia over the period covered by the Asian crisis. He used three asymmetric models of conditional volatility (GJR, NGARCH and AGARCH), he found evidences of significant asymmetric impacts from conditional volatility shocks, with negative shocks causing greater volatility than positive shocks, during the Asian crisis. We add to the existing literature in this area by providing up to date evidence on this issue for the G-7 and provide new evidence on the extent to which volatility spillovers vary between different currencies and the domestic stock market in each country.

\section{Data and Methodology}

The analysis will be conducted with the purpose of investigating volatility spillovers between stock returns and exchange rate changes for the G-7 (Canada, France, Germany, Italy, Japan, UK and USA) for the period 1 January 1996 to 31 December 2006. . In order to analyse the relationship between these two variables, we split our sample into three sub samples which provide more detail and a better understanding of volatility spillovers between stock returns and exchange rates. Therefore, initially we which analyse the relationship between these two variables before the introduction of the Euro, so our first sub sample will analyse 1996-1998. Then we analyse the time period after the introduction of the Euro from 1999-2006. We are interested in examining whether the first years of the single currency in the European financial markets affected the relationship between our variables, so we split our sample into two sub periods;1999-2001 covers the period that markets were working with the single currency but without physically being introduced. Finally we analyse from 2002-2006 where the Euro was physically introduced in the financial markets, allowing us to observe the behaviour of our variables when the Euro settled in European Monetary Union. The data set consists of daily closing values for the stock market indices in each country, as well as daily closing values for the exchange rates of each country against the Euro, DM, UK£, Swiss Franc (CHF), Japanese Yen and the US\$. We include these exchange rates to examine whether volatility spillovers are stronger from certain currencies during the sample period. The original data set was subject to some modifications, all holidays and other closing days were removed from the sample in order to avoid inconsistencies with the data set and also in order to avoid problems in the modelling estimation. Data was taken from DataStream and the Federal Reserve Statistic Release, giving a total of 2766 observations for each series. Following Kanas (2000) we use continuously compounded stock returns and exchange rate changes calculated as the first differences of the natural $\log$. That is, $\mathrm{S}=\mathrm{Stock}$ Prices; $S_{t}=\ln \left(P_{t}^{s}\right)-\ln \left(P_{t-1}^{s}\right)$ and E= Exchange Rates; $E_{t}=\ln \left(P_{t}^{e}\right)-\ln \left(P_{t-1}^{e}\right)$.

As an initial step we provide descriptive statistics for stock returns and exchange rates, in order to summarise the statistical characteristics of our sample. We then proceed and perform a stationarity test on each of the relevant variables that are included in our analysis to ensure that the results from the analysis are not spurious. We apply the Dickey Fuller (DF) test, or Augmented DickeyFuller test $(\mathrm{ADF})$ procedure if serial correlation is present. We also apply the Lagrange Multiplier (LMF) test, to ensure that a sufficient number of lags have been added in the ADF test to ensure that there is no serial correlation present and the results of the ADF test are valid. The LMF test is applied given that it is valid in the presence of lagged dependent variables as well as having the advantage of testing for first and higher orders of serial correlation. If our variables are non-stationary in levels, we then proceed and perform a cointegration test on our variables using the Johansen Cointegration test to 
investigate the long-run relationship between Stock Prices and Exchange Rates. As Enders (2004) notes given that the results of the test can be quite sensitive to the lag length, the most common procedure is to estimate a Vector Autoregression (VAR) model on the undifferenced data in order to determine the lag length for the Johansen test. We estimate the lag selection tests up 20 lags. In terms of choosing between the various lag length selection criteria we follow Johansen et al.(2000) who suggest that when different information criteria suggest different lag lengths, it is common practice to prefer Hannan-Quinn (HQ) criteria. Again, we ensure that the lag length selected for the VAR model is free from serial after performing by applying the LMF test to test for serial correlation up to the number of lags in the VAR model. There are five possible models to choose from for the Johansen test as follows.

$$
\begin{aligned}
& H_{2}(r): \Pi y_{t-1}+B x_{t}=\alpha B^{\prime} y_{t-1} \\
& H^{*}(r): \Pi y_{t-1}+B x_{t}=\alpha\left(B^{\prime} y_{t-1}+p_{0}\right) \\
& H_{1}(r): \Pi y_{t-1}+B x_{t}=\alpha\left(B^{\prime} y_{t-1}+p_{0}\right)+\alpha \perp \gamma_{0} \\
& H^{*}(r): \Pi y_{t-1}+B x_{t}=\alpha\left(B^{\prime} y_{t-1}+p_{0}+p_{1} t\right)+\alpha_{\perp} \gamma_{0} \\
& H(r): \Pi_{t-1}+B x_{t}=\alpha\left(B^{\prime} y_{t-1}+p_{0}+p_{1} t\right)+\alpha_{\perp}\left(\gamma_{0}+\gamma_{1} t\right)
\end{aligned}
$$

Equation 1 has no deterministic trends in the level data and no intercepts in the cointegrating equations. Equation 2 has no deterministic trends in the level data and the cointegrating equations have intercepts. Equation 3 has linear trends in the level data but the cointegrating equations only have intercepts. Equation 4 has linear trends in both the level data and the cointegrating equations, and equation 5 has quadratic trends in the level data and linear trends in the cointegrating equations. Harris and Sollis (2003) note that model 1 i.e. with no deterministic components in the data or cointegration relations, is unlikely to occur in practice, as generally an intercept is needed to take account of the units of measurement of the variables; they also note that model 5 with quadratic trends, is economically hard to justify, as if the variables are entered in logs, as they are in our model, as this would imply an every increasing or decreasing rate of change. This leaves a choice between models 2-4. Johansen (1992) suggests choosing the appropriate model according to the Pantula principle; all three models are estimated; the Pantula principle involves moving through each model for the null hypothesis of $r=0$, then $r=1$ etc., and picking the model where the null hypothesis is rejected for the first time. Chang and Caudill (2005) note that the $\lambda_{\text {trace }}$ test statistic is more robustness to both skewness and excess kurtosis than the $\lambda_{\max }$ test statistic; for comparative purposes, we show both the results of the $\lambda_{\text {trace }}$ and the $\lambda_{\max }$ test statistics.

We then proceed with our volatility analysis and apply a bivariate extension of the EGARCH $(p, q)$ model in order to examine whether the volatility of stock returns affects and is affected by the volatility of exchange rate changes within each economy. The EGARCH specification (Nelson, 1991) is used in order to test whether the volatility spillover effects are asymmetric. For example, an asymmetric spillover from stock returns to exchange rate changes would suggest that the effect of "bad" stock market news on the exchange rate change is greater than the effect of "good" news. The model is specified as follows:

$$
\begin{aligned}
S_{t} & =a_{s, 0}+\sum_{i=1}^{r} a_{s, i} S_{t-i}+\sum_{i=1}^{r} a_{e, i} E_{t-i}+\beta_{s} \lambda_{s, t-1}+e_{S, t} \\
E_{t} & =a_{E, 0}+\sum_{i=1}^{r} a_{E, i} E_{t-i}+\sum_{i=1}^{r} a_{S, i} S_{t-i}+\beta_{E} \lambda_{E, t-1}+e_{E, t} \\
e_{S, t} / \Omega_{t-1} & \approx N\left(0, \sigma_{S, t}^{2}\right) \\
e_{E, t} / \Omega_{t-1} & \approx N\left(0, \sigma_{E, t}^{2}\right)
\end{aligned}
$$


The conditional variances of stock returns and exchange rates changes are specified as follows:

$$
\begin{aligned}
& \sigma_{S, t}^{2}=\exp \left\{c_{S, 0}+\sum_{j=1}^{p s} b_{S, j} \log \left(\sigma_{S, t-j}^{2}\right)+\delta_{S, S}\left[\left(\left|z_{S, t-1}\right|-E\left|z_{S, t-1}\right|+\theta_{S, S z_{s, T-1}}\right)+\delta_{S, E}\left[\left(\left|z_{E, t-1}\right|-E\left|z_{E, t-1}\right|+\theta_{S, E z E, t-1}\right)\right]\right]\right. \\
& \sigma_{E, t}^{2}=\exp \left\{c_{E, 0}+\sum_{j=1}^{p s} b_{E, j} \log \left(\sigma_{E, t-j}^{2}\right)+\delta_{E, E}\left[\left(\left|z_{E, t-1}\right|-E\left|z_{E, t-1}\right|+\theta_{E, E z_{s, T-1}}\right)+\delta_{E, S}\left[\left(\left|z_{S, t-1}\right|-E\left|z_{S, t-1}\right|+\theta_{E, S Z E, t-1}\right)\right]\right.\right. \\
& \sigma_{S, E, T}=\rho_{S, E} \sigma_{S, t} \sigma_{E, t}
\end{aligned}
$$

We summarise each of the relevant terms in equations (6-9) in Table 1.

Table 1 Description of Parameters Equations (6)-(9)

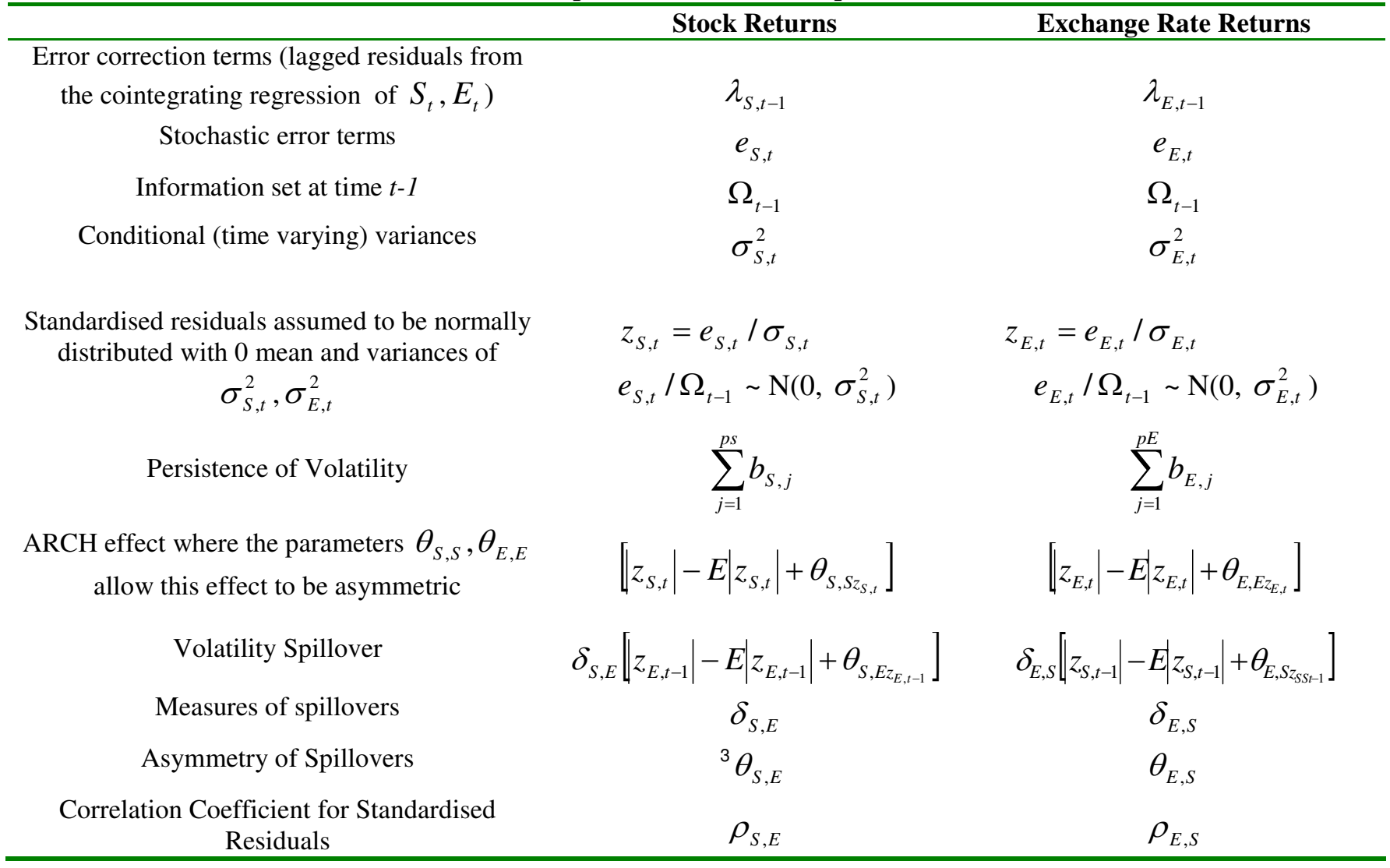

We specify the number of lags for the conditional mean equations (6) and (7) using the HQ criterion; Griffin et al (2005) Andersen et al (2004) and Stulz et al (2002) all note that the HannanQuinn selection criterion is preferable to the more commonly used Akaike's Information Criteria (AIC), as the latter tends to overparameterize the models ${ }^{4}$. Next we apply the likelihood ratio (LR) test to determine the lag truncation length, $p$. We perform separate LR test on the stock returns and exchange rate conditional variance equations (8) and (9) to determine the optimal lag length for the EGARCH specification of each equation. Hamilton (1994) defines the LR test as follows:

${ }^{3} \theta_{S, E}<0, \theta_{S, E}<0$, implies that negative exchange rate shocks increase the volatility of stock returns more than positive shocks

${ }^{4}$ For brevity here we do not report the number of lags selected for the conditional mean equations for stock prices and exchange rates for each period. 
$2[L(\hat{\theta})-L(\tilde{\theta})] \approx \chi^{2}(m)$, where $L(\hat{\theta})$ denotes the value of the log likelihood function at the unrestricted estimate and $L(\tilde{\theta})$ denotes the value of the $\log$ likelihood function of the restricted estimate. Bollerslev-Woolridge robust $t$-statistics are derived to take into account possible non-normality of the residuals. All results are generated using the EVIEWS statistical program.

\section{Empirical Results}

Our analysis begins by providing descriptive statistics for stock returns and exchange rates, in order to summarise the statistical characteristics of our sample which are set out in Tables 2 to 5. For the stock returns of each country for 1996-98 we found that the means are positive in all the cases, with the exception of the NIKKEI 225. During 1999-2001 the sample means of stock returns are positive in the case of Canada, France and the US, while for Germany, Italy, Japan and the UK stock returns means are negative. During 2002-2006 the means of all the indices are positive. The standard deviations of the stock returns provide information about the volatility of the markets during the three periods. In general, all the markets show higher volatility during the initial years of the introduction of the Euro on financial markets, that is during 1999 to 2001. The SD ranges from 1.23\%(Dow Jones) to $1.58 \%$ (Dax 30). The standard deviations for 2002-2006 range from $0.81 \%$ (S\&P/TSX Composite) to $1.61 \%$ (DAX 30). The skewness and kurtosis coefficients indicate that stock returns are leptokurtic relative to the normal distribution, which Caporale et al. (2002) note is a common finding for stock returns. The Jarque-Bera test also rejects the hypothesis that stock returns are normally distributed in all the cases.

The descriptive statistics for the exchange rate returns are presented is for each country, to capture the behaviour of the exchange rates on an individual basis. Overall there is a wide variation in the sign and magnitude of the means and standard deviations both over time, across countries and across the various bilateral exchange rates we include in the analysis. For Canada, during 1996-1998 the means of the exchange rates are positive in the case of $\mathrm{C} \$ / \$, C \$ / £$ and $\mathrm{C} \$ / \neq$, while $\mathrm{C} \$ / \mathrm{CHF}$ and $\mathrm{C} \$ / \mathrm{DM}$ means are negative. During 1999-2001 the means for the $\mathrm{C} \$ / €, \mathrm{C} \$ / \$$ are positive while $\mathrm{C} \$ / \mathfrak{f}$, $\mathrm{C} \$ / \neq$ and $\mathrm{C} \$ / \mathrm{CHF}$ are negative, and during 2002-2006 the mean for all the exchange rates are negative. The SD shown that as with the stock returns, the exchange rates are more volatile during the first years of the introduction of the Euro on financial markets, the SD range from $0.36 \%(C \$ / \$)$ to $0.79 \%(C \$ \%)$.

For the period prior to the introduction of the Euro for France, the means are positive in the case of Franc/\$, Franc/£ and Franc/ $¥$, while the means are negative for Franc/CHF and Franc/DM. For Germany, the means for $\mathrm{D} / \$, \mathrm{DM} / £, \mathrm{DM} / ¥$ are positive, while DM/CHF mean is negative. For Italy, for this period the means are positive for Lira/\$, Lira/£, while Lira/ $¥, \mathrm{Lira} / \mathrm{CHF}$ and Lira/DM are negative.

During 1999-2001 the $€ / \$$ and $€ / £$ means are negative while the $€ / ¥$ and $€ / C H F$ are positive this situation reverses during 2002-2006 where the $€ / \$$ and $€ / £$ means are positive and the $€ / ¥$ and $€ / C H F$ means are negative. As with Canada, we also found that in this case the volatility in the exchange rates is higher during the 1999-2001 than in the other periods, ranging from $0.24 \%(€ / C H F)$ and $0.90 \%$ (€/¥).

For Japan during 1996-1998 the means for the $¥ / \$$, and $¥ / \mathfrak{£}$ are positive while $¥ / \mathrm{CHF}$ and $¥ / \mathrm{DM}$ are negative, during 1999-2001 the ¥/€ and $¥ / C H F$ the means are negative while $¥ / \$$ and $¥ / \mathfrak{E}$ are positive, and finally during 2002-2006 the means are positive in all the cases with the exception of $¥ / \$$ which is negative. The volatility of these markets was higher during 1999-2001 period, as in the previous cases, with the SD range from $0.71 \%$ ( $¥ / \$$ ) to $1 \%$ (¥/CHF).

For the UK for 1996-1998 the means for all the exchange rates are negative. During 1999-2001 the means are positive in all the cases with the exception of £/CHF, and during 2002-2006 the means are negative in all cases. The SD coefficients indicates that the exchange markets were more volatile 
during 1999-2001 than in the other periods, where volatility range from $0.51 \%$ ( $£ / €$ and $£ / \$$ ) to $1 \%$ $(£ / ¥)$.

For the US the mean coefficients are positive during 1996-1998 in all the cases, with the exception of $\$ / £$. During 1999-2001 the means are negative in all the cases with the exception of $€ / £$ were the means are positive, and finally during 2002-2006 the means are positive with the exception of $\$ / €$ that is negative. The SD coefficients show that again the exchange rates were more volatile during 1999-2001 than in the rest of the period, ranging from $0.49 \%$ (\$/£) to $0.7 \%(\$ / ¥)$.

The skewness and kurtosis statistics for all countries and bilateral exchange rates in all periods indicate that the distribution of exchange rate returns in all the cases for all the countries are nonnormal and the Jarque-Bera test also rejects the hypothesis of normally distributed returns for all periods for all exchange rates.

The results from the ADF tests are given in Tables 6 and 7. The values of the test statistics indicate that we can reject the null hypothesis of the existence of unit root in levels for all variables in all periods indicating that all series are $I(0) .^{5}$ Given that all variables are integrated of the same order, and also given that they are $I(0)$ processes we proceed directly to perform our volatility analysis using EGARCH $(\mathrm{p}, \mathrm{q})$ modelling.

In order to establish the correct lag length for the EGARCH model, we apply the Likelihood Ratio test. The results from this test for each country are set out in Table 8. Dealing firstly with the stock return equeations, for the 1996-1998 period, we chose the EGARCH $(1,1)$ model for the $\mathrm{DM} / \$$ for Germany and for the $\$ £, \$ /$ Yen and $\$ D M$ for the US. For the 1999-2001 period we chose the EGARCH $(1,1)$ for Canada for the $\mathrm{C} \$ / \mathrm{C} \$ /$ Yen and $\mathrm{C} \$ \mathrm{CHF}$. For Germany and Japan for this period this model was also chosen for all bilateral exchanges rates. For the 2002-2006 period for France for the $€ / \$$ and $€ /$ Yen, as well as for Germany for the $€ /$ Yen and for Japan for all bilateral exchange rates the $(1,1)$ model was selected on the basis of the LR results. For all countries for all other exchange rates for the EGARCH $(2,1)$ model was selected for the stock return equation.

For the exchange rate equation, for the 1996-1998 period we selected the EGARCH $(1,1)$ model for Canada for C $\$$, for France for FR/DM, for Germany for DM. $\$$ and for Japan for Y/CHF. For the 2002-2006 period, again for Canada we selected the $(1,1)$ model for $C \$ / \$$ and $C \$ / £$, for France and Italy for $€ / \$$, for the $U K$ for $£ / €, \$ / C H F$ and finally for the US for the $\$ / €$ and $\$ / £$. Again for all countries for all other exchange rates in each period, the $\operatorname{EGARCH}(2,1)$ model was chosen for the exchange rate equation.

The estimated parameters from the EGARCH estimation are set out in Tables 9-17, for the three periods of analysis (1996-1998, 1999-2001 and 2002-2006).

Firstly, in relation to the coefficients on the volatility persistence term, the results vary depending on the country, the equation but we find that the majority of terms are significant for both the stock returns and exchange rate changes. This is not surprising given that persistence is a feature of many financial markets data. Regarding the significance of volatility persistence in stock returns, Italy was the only country for which the volatility persistence term was significant in all periods across all bilateral exchange rates; France also showed consistency across all time periods for all exchange rates with only the $€ / C H F$ not significant in 2002-2006. There appears to be more consistency between the pre Euro period and the 2002-2006 period for certain countries; for example, for Canada and the UK, all bilateral exchange rates are significant for the stock return equation in both periods but insignificant for the 1998-2001 period. While all coefficients were significant across all exchange rates for Japan in the pre-Euro period, there was no significant persistence evident in after the introduction of the Euro. In contrast, there was no significant volatility persistence in the US apart from the \$/CHF prior to the Euro and for the 1999-2001 period, but for 2002 all bilateral exchange rates in the stock return. For the persistence of volatility of exchange rates, an interesting feature of our results which reflects our analysis of more than one exchange rate is that the persistence of volatility of exchange rates varies

\footnotetext{
${ }^{5}$ The LMF test results indicated that the ADF tests were free from serial correlation; for brevity we do not show the test results here.
} 
depending on which bilateral exchange rate is included in the EGARCH model. Overall, there appears to be more widespread persistence in the 1996-1998 period and the 2002-2006 period than the 19912001 period for Canada, Japan, Germany and Italy. Only for the US and France was there more significant volatility persistence across exchange rates in the 2002-2006 period than in the periods prior to this, while for the UK the 2002-2006 period showed a decline in the significance of volatility persistence across exchange rates compared to the earlier periods. Thus the impact of the introduction of the Euro on the persistence of the volatility of stock returns and exchange rates has not had a uniform impact across the financial markets in the G-7. Wu (2005) notes that a necessary condition for the volatility persistence terms to be stable is that the value of the estimated coefficients should be less than one; for our results, this applies in all cases for the three periods for the persistence terms for both stock returns and exchange rates where we the magnitude of the coefficients are all less than one.

In terms of the coefficients for the volatility spillover effects, firstly there is a large degree of consistency across counties and time periods for spillovers from stock returns to exchange rate changes. We find significant spillovers at 5\% level for Canada, France, Japan and the UK for all periods for all bilateral exchange rates. For Germany in the period prior to the introduction of the Euro the $\mathrm{DM} / \$$ was the only exchange rate for which there was not significant volatility spillovers from the stock market with significant spillovers evident from the stock market to all exchange rates post 1999. Thus the volatility of stock returns has been an important influence and determinant of volatility of all bilateral exchange rates we included in our analysis in these countries. Furthermore, the impact of stock market volatility on exchange rates has not been altered significantly by the introduction of the Euro in the sense that the cross exchange rates against the $\$$, Yen, $£$ and CHF existed prior to the introduction of the Euro as well as after it across nearly all g-7 markets. In addition to this, we find that for the pre Euro period, Italy was the only country in the G-7 for which there was no volatility spillover effects from the stock market to any of the bilateral exchange rates included in our analysis. After the Euro was introduced, the $\$ / £$ exchange rate was the only exchange rate where no volatility spillovers were evident from the US stock market at 5\% level, although this was significant at $10 \%$ level.

The significant coefficients indicate that the volatility of stock returns was a determinant of the volatility of the exchange rate and that information contained in stock prices impacted on the behaviour of exchange rates in these markets. Significant coefficients are also indicative of integration between stock markets and exchange rate markets; given that the G-7 markets are the most developed financial markets globally, the existence of integration is not surprising. In addition, the lack of these spillovers in Italy in the pre Euro period can be taken as evidence that the stock and money markets in Italy were not as integrated as in other more developed G-7 countries. Furthermore, where the coefficients are insignificant indicates that prior to the introduction of the Euro there was some potential for diversification between stock markets and currency markets in these countries.

In terms of volatility spillovers from exchange rates to stock markets, the results are less significant across countries and over time. For the 1996-1998 period, Canada, Germany and Italy had no significant spillovers. For the other countries included in the analysis, there were a number of bilateral exchange rates where significant spillovers were evident from exchange rates to stock returns at 5\% level; for the period prior to the introduction of the Euro, they were for France for the FR/DM, for Japan for the Yen/CHF, for the UK for the $£ / \$$ and for the US for the $\$ / £$ exchange rates. After the Euro there is some commonality regarding which exchange rates we find significant volatility spillover effects for stock markets. That is, for the $€ / Y e n$ and Yen/CHF the volatility spillovers were significant for the stock markets in France, Germany and Italy, the Yen/€ and Yen/CHF for the Japanese stock market, the $£ / €$ and $£ / C H F$ for the UK and the $\$ / \$$ for the US. For the 2002-2006 period, again there were only a small number of all exchange rates included for which we observed significant volatility spillovers into stock markets; for Canada for the $\mathrm{C} \$ / £$, for Japan for Yen/£, for the UK for the $£ / €$ and $£ / \$$. No significant spillovers were evident in France, Germany or Italy. 
The lack of significant spillovers from exchange rate changes to stock returns found here for some countries across a number of exchange rates is consistent with results from Jorion (1990) as well as with Yang and Doong (2005). Jorion (1990) explained the lack of spillovers as possibly due to positive exchange rate volatility on stock returns for some firms offsetting negative exchange rate volatility on stock returns for other firms to give an insignificant or weak effect overall. In addition to this, the use of instruments to hedge exchange rate risk, may reduce the impact of exchange rate volatility on stock markets; Grant and Marshall, 1997, and Bodnar et al. (1995) both note that the use of hedging instruments to ameliorate exchange rate risk is pervasive amongst larger companies which are the main components of national stock market indices. The lack of significant spillovers from exchange rates to stock markets in the pre Euro period could be indicative of wider use of hedging by firms listed on the stock markets in these countries than after the introduction of the Euro. It may also be the case that the adoption of the Euro brought greater volatility to certain stock markets given the global nature of the currency which they would not have been exposed to prior to the Euros introduction.

A positive sign on the spillover coefficient indicates that an increase in volatility in one market is associated with increased volatility in the other market while a negative coefficient indicates that increase volatility in one market is associated with decreased volatility in the other market. In our results, we found a mixture of positive and negative significant coefficients for the two spillover terms in all periods; this indicates that the impact of volatility from exchange rate markets to stock markets or vice versa is not constant either over time for the same country, or across countries for the same period of time.

For the asymmetric spillover effects from stock returns to exchange rates we found that the coefficients are significant in all the cases for all the periods. Analysing asymmetric spillover effects from exchange rates to stock returns we found some differences, during 1996-1998 the coefficients are significant in almost all the cases, with the exception of Canada were the C\$/DM is insignificant, France show an insignificant coefficient in the case of $F R / \$$, for Germany $D M / \$$ is insignificant and finally the \$/DM for US is insignificant as well. During 1999-2001 we found the same characteristics, in general terms the coefficients are significant but there are few exceptions in relation to the following countries were the coefficients are insignificant: in the case of Canada we found that the coefficients are insignificant for $\mathrm{C} \$ / \$, C \$ / £$ and $\mathrm{C} \$ / €$, for France and Germany and Italy the $€ / £$ and finally for the US the $\$ / C H F$. Analysing the last period 2002-2006 our results show that again the coefficients are significant in almost all the cases, just few exceptions were found where the coefficients are insignificant, in the case of Japan the $¥ / \$$ and the $¥ / £$, for the UK the $£ / €$ and for the US the $\$ / £$ and the

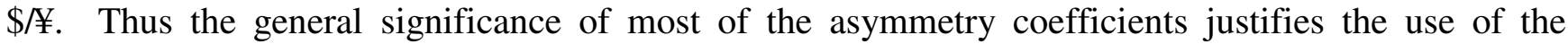
EGARCH model to capture this asymmetry in the impact of good and bad news. The existence of insignificant coefficients indicates that the spillover effects in these instances are symmetric, that is that positive and negative shocks have the same impact on volatility.

The diagnostic tests on the standardised residuals are listed for each country in Table 18. The Jarque-Bera test indicates that we reject the hypothesis that the residuals are normally distributed. Hence, this justifies the use of the Bollerslev-Woolridge robust $t$-statistics. The Ljung-Box statistics for all three periods for all countries indicate that there are no residual linear or non linear dependencies. There are some exceptions where the coefficient was not significant but the problem was corrected after introducing more lags into the test. Finally to check the validity of the assumption of constant correlation adopted in the estimation of the bivariate models (Kanas, 2000), the LB statistics for the cross products of the standardised residuals from the stock returns equation and from the exchange rate equation are calculated and these statistics indicated that the assumption of constant correlation over time can be accepted. 


\section{Conclusions}

Relationships between equity returns and exchange rates are of particular interest for academics and practitioners due to the fact that these two variables play a crucial role in portfolio and risk management. Equity returns and exchange rate movements may be used to hedge portfolios against currency movements, where risk management has to take into consideration the linkages between these to markets in order to design appropriate strategies.

This paper set out to examine the volatility linkages between stock returns and exchange rates in the G-7 markets. While there is a significant body of evidence which investigates the relationship between the first moments of exchange rates and stock returns, the evidence on volatility linkages between the two markets is scarce and has generally been confined to investigation of the relationship for stock returns and a single exchange rate. Our analysis was thus broader in scope than existing research in that we included a number of bilateral exchange rates in our analysis which permitted us to examine whether volatility spillovers exist to the same extent across exchange rates so increasing our understanding of the nature of integration between stock and exchange rate markets in the G-7 countries. In addition to this, no research to date has explicitly focused on the impact of the introduction of the Euro on volatility spillovers between these financial markets. In order to address this gap in the literature, we examined three main periods, covering the time period before the introduction of the Euro, immediately after the introduction of the Euro but when the currency was still not in circulation, and finally the period covering when the currency was physically introduced.

Our results overall show that the volatility of stock prices affects the volatility of exchange rates in a much more widespread way than the volatility of exchange rates affecting the volatility of stock prices. Our results are thus consistent with those of Kanas (2000) and Yang and Doong (2004) who both found evidence of volatility spillovers from stock returns to exchange rates but no evidences of spillovers in the opposite direction. The lack of significant spillovers in these markets indicates that there is potential for diversification between stock markets and currency markets in certain instances. The difference between our results and existing studies on volatility spillovers between exchange rates and stock markets could reflect the larger number of bilateral exchange rates included in our analysis. Thus further research along these lines is required in order to establish more comprehensively the true nature of spillovers from exchange rates to equity markets which should provide valuable information on the possibilities for diversifying holdings of stocks and currencies in investment portfolios, as well as the potential for hedging amongst these assets. 


\section{References}

Assoé, K. (2001), 'Volatility Spillovers Between Foreign Exchange and Emerging Stock Markets'. CETAI (Centre d'études en administration internationale. Cahier de recherché 2001-04.

Bollerslev, T., (1986), Generalized autoregressive conditional heteroscedasticity, Journal of Econometrics, Vol. 31, pp.307-327.

Branson, W. (1983), 'Macroeconomic Determinants of Real Exchange Rate Risk', in R. Herring (Ed.), Managing Foreign Exchange Risk, MA: Cambridge University Press.

Caporale, M., Pittis, N. and Spagnolo, N, 'Testing for Causality-in-Variance: An application to the East Asian Markets', International Journal of Finance and Economics, Vol. 7, pp/235-245.

Chang, T. and Caudill, S., (2005), 'Financial Development and Economic Growth: The Case of Taiwan', Applied Economics, Vol. 37, pp.1329-1335.

Dornbusch, R., and Fischer, S., (1980), 'Exchange Rates and the Current Account, American Economic Review, Vol. 12, pp.7-12.

Enders, W., (2004), Applied Econometric Time Series. Chichester, UK: Wiley.

Fang, W., (2002), The effect of currency depreciation on stock returns: evidence from five East Asian economies, Applied Economics Letters, Vol.9, pp.195-199.

Frankel, J., (1983), 'Monetary and Portfolio-Balance Models of Exchange Rate Determination', in J. Bhandari and B. Putman (Eds), Economic Interdependence and Flexible Exchange Rates, MA, MIT Press.

Hamilton, J., (1994), Time Series Analysis, Princeton: Princeton University Press.

Johansen, S., (1992), Determination of cointegration rank in the presence of a linear trend, Oxford Bulletin of Economics and Statistics, Vol 54, pp.383-397.

Johansen, S., Mosconi, R and Nielsen, B., (2000), Cointegration analysis in the presence of structural breaks in the deterministic trend, Econometrics Journal, Vol. 3, pp.216-249.

Jorion, P. (1990), The Exchange Rate Exposure of US Multinationals, Journal of Business, Vol.63, pp.331-45.

Kanas, A. (2000), Volatility Spillovers Between Stock Returns and Exchange Rate Changes: International Evidence, Journal of Business Finance and Accounting, Vol. 27, pp. 447-467.

Kanas, A. (2002), Is Exchange Rate Volatility Influenced by Stock Return Volatility? Evidence from the US, the UK and Japan, Applied Economics Letters, Vol. 9, 501-503.

Koutmos, G., and Booth, G., (1995), 'Asymmetric Volatility Transmission in International Stock Markets', Journal of International Money and Finance, Vol. 14, pp.747-762.

Laopodis, N., (1998), 'Asymmetric Volatility Spillovers in Deutsche Mark Exchange Rates', Journal of Multinational Financial Management, Vol.8, pp.413-430.

Leeves, G., (2007) 'Asymmetric volatility of stock returns during the Asian crisis: Evidence from Indonesia'. International Review of Economics and Finance 16 (2007) 272-286.

Mundell, R., (1963), 'Capital Mobility and Stabilization Policy under Fixed and Flexible Exchange Rate", Canadian Journal of Economics and Political Science, Vol. 29, pp.475-467.

Mundell, R., (1964), A reply: Capital Mobility and Size', Canadian Journal of Economics and Political Science, Vol. 30, pp.421-431.

Nelson, D., (1991), 'Conditional Heteroscedasticity in Asset Returns: A New Approach, Econometrica, Vol. 59, pp.347-370.

Nieh, C.C and Lee, C.F, (2001), Dynamic Relationship between Stock Prices and Exchange Rates for G-7 Countries. The Quarterly Review and Finance 41, pp. 477-490.

Qayyum, A. and Kemal A.R.,(2006) 'Volatility Spillover Between the Stock Market and the Foreign Exchange Market in Pakistan'. MPRA (Munich Personal RePEc Archive. Paper n.1715, , posted 08.February 2007.

Smith, C., (1992), 'Stock Markets and the Exchange Rate: A Mutli-Country Approach', Journal of Macroeconomics, Vol. 14, pp.607-629.

Wu, R., (2005), International Transmission Effect of Volatility between the Financial Markets during the Asian Financial Crises, Transition Studies Review, Vol. 15, pp. 19-35.

Yang, S. and Doong, S., (2004), 'Price and Volatility Spillovers between Stock Prices and Exchange Rates: Empirical Evidence from the G-7 Countries', International Journal of Business and Economics, Vol. 3, pp.139-153.

Yau, H. and Nieh, C.C., (2006), Interrelations among Stock prices of Taiwan and Japan and NTD/Yen Exchange Rate, Journal of Asian Economics, Vol. 17, pp. 535-552.

Zapatero, F., (1995), 'Equilibrium Asset Prices and Exchange Rates', Journal of Economic Dynamics and Control, Vol. 19. pp.787-811. 
Table 2 Descriptive Statistics Stock Returns

\begin{tabular}{lccccc}
\hline & Mean & SD & Skewness & Kurtosis & JB \\
\hline 1996-1998 & & & & & \\
S\&P/TSX Composite & 0.000408 & 0.0092 & -1.2067 & 11.7138 & 2568 \\
CAC 40 & 0.000962 & 0.0133 & -0.1264 & 5.6589 & 224 \\
DAX 30 & 0.001027 & 0.0145 & -0.3719 & 6.2860 & 357 \\
MIB 30 & $5.24 \mathrm{E}-05$ & 0.0127 & -0.2050 & 6.1065 & 822 \\
NIKKEI 225 & -0.00048 & 0.0149 & 0.1413 & 5.7485 & 240 \\
FTSE 100 & 0.000619 & 0.0101 & -0.1328 & 4.8311 & 108 \\
Dow Jones & 0.00076 & 0.0109 & -0.7291 & 9.0648 & 1222 \\
1999-2001 & & & & & \\
S\&P/TSX Composite & 0.000228 & 0.0133 & -0.4666 & 6.2841 & 352 \\
CAC 40 & 0.000145 & 0.0143 & -0.1723 & 3.7704 & 22 \\
DAX 30 & $-3.31 \mathrm{E}-05$ & 0.0158 & -0.1669 & 4.2393 & 52 \\
MIB 30 & -0.0002 & 0.0147 & -0.2199 & 5.3724 & 183 \\
NIKKEI 225 & -0.00032 & 0.0151 & 0.0152 & 4.9564 & 120 \\
FTSE 100 & -0.00016 & 0.0127 & -0.3770 & 4.5325 & 86 \\
Dow Jones & 0.000116 & 0.0123 & -0.3880 & 5.7630 & 258 \\
2002-2006 & & & & & \\
S\&P/TSX Composite & 0.000425 & 0.008127 & 0.0097 & 5.6228 & 347 \\
CAC 40 & 0.000152 & 0.0141 & -0.0357 & 7.2778 & 958 \\
DAX 30 & 0.000194 & 0.0161 & -0.0582 & 6.7782 & 747 \\
MIB 30 & 0.00021 & 0.0112 & -0.1440 & 6.1939 & 538 \\
NIKKEI 225 & 0.000391 & 0.0127 & -0.2084 & 4.1589 & 79 \\
FTSE 100 & 0.000153 & 0.0114 & 0.2547 & 11.4587 & 3504 \\
Dow Jones & 0.000172 & 0.0100 & 0.3669 & 6.9579 & 847 \\
\hline
\end{tabular}


Table 3 Descriptive Statistics Exchange Rates 1996-1998

\begin{tabular}{|c|c|c|c|c|c|}
\hline & Mean & SD & Skewness & Kurtosis & JB \\
\hline \multicolumn{6}{|l|}{ CANADA } \\
\hline $\mathrm{C} \$ / \$$ & 0.000165 & 0.0029 & -0.0828 & 7.1026 & 530 \\
\hline $\mathrm{C} \$ / £$ & 0.000253 & 0.0055 & -0.0605 & 4.9201 & 116 \\
\hline $\mathrm{C} \$ / ¥$ & $5.29 \mathrm{E}-05$ & 0.0087 & 0.7794 & 7.3918 & 682 \\
\hline $\mathrm{C} \$ / \mathrm{CHF}$ & $-6.22 \mathrm{E}-05$ & 0.0071 & 0.6768 & 5.0271 & 187 \\
\hline $\mathrm{C} \$ / \mathrm{DM}$ & $-3.34 \mathrm{E}-05$ & 0.0061 & 0.4390 & 4.1136 & 63 \\
\hline \multicolumn{6}{|l|}{ FRANCE } \\
\hline FRANCS/\$ & 0.000173 & 0.0052 & -0.2988 & 4.1836 & 55 \\
\hline FRANCS/£ & 0.000261 & 0.0053 & -0.2789 & 4.0171 & 42 \\
\hline FRANCS/¥ & $6.13 \mathrm{E}-05$ & 0.0077 & 0.6667 & 6.7006 & 486 \\
\hline FRANCS/CHF & $-5.38 \mathrm{E}-05$ & 0.0029 & 0.0289 & 4.6822 & 89 \\
\hline FRANCS/DM & $-2.50 \mathrm{E}-05$ & 0.0011 & -0.2162 & 6.0925 & 306 \\
\hline \multicolumn{6}{|l|}{ GERMANY } \\
\hline $\mathrm{DM} / \$$ & 0.000198 & 0.0053 & -0.2665 & 4.1385 & 50 \\
\hline $\mathrm{DM} / £$ & 0.000286 & 0.0052 & -0.2564 & 3.6515 & 22 \\
\hline $\mathrm{DM} / ¥$ & $8.63 \mathrm{E}-05$ & 0.0077 & 0.6796 & 6.7852 & 508 \\
\hline DM/CHF & $-2.88 \mathrm{E}-05$ & 0.0029 & 0.0380 & 4.9698 & 122 \\
\hline \multicolumn{6}{|l|}{ ITALY } \\
\hline LIRA/\$ & $6.91 \mathrm{E}-05$ & 0.0049 & -0.1731 & 4.0160 & 36 \\
\hline LIRA/£ & 0.000157 & 0.0051 & -0.2416 & 3.8240 & 29 \\
\hline LIRA/¥ & $-4.29 \mathrm{E}-05$ & 0.0078 & 0.7519 & 6.8662 & 541 \\
\hline LIRA/CHF & -0.00016 & 0.0039 & 0.3086 & 5.4278 & 197 \\
\hline LIRA/DM & -0.00013 & 0.0027 & 0.1394 & 10.1224 & 1596 \\
\hline \multicolumn{6}{|l|}{ JAPAN } \\
\hline$¥ / \$$ & 0.000112 & 0.0083 & -1.0488 & 8.9635 & 1256 \\
\hline$¥ / £$ & 0.0002 & 0.0087 & -0.5002 & 5.9988 & 314 \\
\hline$¥ / \mathrm{CHF}$ & -0.00012 & 0.0078 & -0.5877 & 5.9964 & 325 \\
\hline$¥ / \mathrm{DM}$ & $-8.63 \mathrm{E}-05$ & 0.0077 & -0.6796 & 6.7852 & 508 \\
\hline \multicolumn{6}{|l|}{ UK } \\
\hline$£ / \$$ & $-8.76 \mathrm{E}-05$ & 0.0047 & 0.1766 & 5.6793 & 229 \\
\hline$£ / ¥$ & -0.0002 & 0.0087 & 0.5002 & 5.9988 & 314 \\
\hline$£ / \mathrm{CHF}$ & -0.00032 & 0.0060 & 0.2784 & 3.9091 & 36 \\
\hline$£ / \mathrm{DM}$ & -0.00029 & 0.0052 & 0.2564 & 3.6515 & 22 \\
\hline \multicolumn{6}{|l|}{ US } \\
\hline$\$ / £$ & $8.76 \mathrm{E}-05$ & 0.0046 & -0.1765 & 5.6793 & 229 \\
\hline$\$ / ¥$ & -0.00023 & 0.0062 & 0.45614 & 4.6274 & 109 \\
\hline \$/CHF & -0.00011 & 0.0082 & 1.0487 & 8.9635 & 1256 \\
\hline \$/DM & -0.0002 & 0.0052 & 0.2665 & 4.1385 & 50 \\
\hline
\end{tabular}


Table 4 Descriptive Statistics Exchange Rates 1999-2001

\begin{tabular}{|c|c|c|c|c|c|}
\hline & Mean & SD & Skewness & Kurtosis & JB \\
\hline \multicolumn{6}{|l|}{ CANADA } \\
\hline $\mathrm{C} \$ / €$ & 0.000604 & 0.0073 & -0.2090 & 3.6311 & 17 \\
\hline $\mathrm{C} \$ / \$$ & $6.08 \mathrm{E}-05$ & 0.0036 & -0.1017 & 3.6845 & 15 \\
\hline $\mathrm{C} \$ / \mathfrak{£}$ & -0.00013 & 0.0061 & 0.1749 & 3.7087 & 19 \\
\hline $\mathrm{C} \$ / ¥$ & -0.00017 & 0.0079 & 0.0648 & 4.3551 & 56 \\
\hline $\mathrm{C} \$ / \mathrm{CHF}$ & -0.0002 & 0.0076 & 0.2368 & 3.7611 & 24 \\
\hline \multicolumn{6}{|l|}{ EURO } \\
\hline$€ / \$$ & -0.00038 & 0.0066 & 0.2486 & 3.9753 & 38 \\
\hline$€ / £$ & -0.0002 & 0.0053 & 0.0808 & 4.0327 & 34 \\
\hline$€ / ¥$ & 0.000169 & 0.0090 & -0.0593 & 4.1008 & 38 \\
\hline$€ / \mathrm{CHF}$ & 0.000118 & 0.0024 & 0.6117 & 12.3531 & 2792 \\
\hline \multicolumn{6}{|l|}{ JAPAN } \\
\hline$¥ / €$ & -0.00017 & 0.0090 & 0.0593 & 4.1008 & 38 \\
\hline$¥ / \$$ & 0.00023 & 0.0071 & -0.1587 & 4.8328 & 104 \\
\hline$¥ / £$ & 4.37E-05 & 0.0081 & 0.0760 & 4.4216 & 62 \\
\hline$¥ / \mathrm{CHF}$ & $-1.97 \mathrm{E}-05$ & 0.0100 & -0.0175 & 4.5574 & 73 \\
\hline \multicolumn{6}{|l|}{ UK } \\
\hline$£ / €$ & 0.000185 & 0.0051 & 0.0059 & 3.8378 & 21 \\
\hline$£ / \$$ & 0.000193 & 0.0051 & -0.0601 & 3.8565 & 22 \\
\hline$£ / \neq$ & $3.82 \mathrm{E}-05$ & 0.0100 & 2.0150 & 19.3181 & 8299 \\
\hline$£ / C H F$ & $-4.87 \mathrm{E}-05$ & 0.0085 & 0.1817 & 3.9171 & 29 \\
\hline \multicolumn{6}{|l|}{ US } \\
\hline$\$ / €$ & 0.000376 & 0.00664 & -0.24884 & 3.9724 & 37 \\
\hline$\$ / £$ & -0.00017 & 0.004915 & 0.150059 & 3.4898 & 10 \\
\hline$\$ \not ¥$ & -0.00021 & 0.007 & 0.157536 & 5.1265 & 145 \\
\hline \$/CHF & -0.00026 & 0.006686 & 0.273988 & 3.8228 & 31 \\
\hline
\end{tabular}


Table 5 Descriptive Statistics Exchange Rates 2002-2006

\begin{tabular}{|c|c|c|c|c|c|}
\hline & Mean & SD & Skewness & Kurtosis & JB \\
\hline \multicolumn{6}{|c|}{ CANADA } \\
\hline $\mathrm{C} \$ / €$ & -0.00042 & 0.0071 & 0.1276 & 3.0984 & 4 \\
\hline $\mathrm{C} \$ / \$$ & -0.00027 & 0.0051 & 0.0323 & 3.3647 & 7 \\
\hline $\mathrm{C} \$ / \mathfrak{£}$ & $-1.18 \mathrm{E}-05$ & 0.0058 & -0.0984 & 3.4803 & 14 \\
\hline $\mathrm{C} \$ / ¥$ & -0.00018 & 0.0078 & 0.1178 & 3.5324 & 17 \\
\hline $\mathrm{C} \$ / \mathrm{CHF}$ & $-1.49 \mathrm{E}-05$ & 0.0083 & -0.0631 & 3.5365 & 15 \\
\hline \multicolumn{6}{|c|}{ FRANCE } \\
\hline$€ / \$$ & 0.000302 & 0.0058 & -0.1429 & 3.4419 & 14 \\
\hline$€ / £$ & $5.99 \mathrm{E}-05$ & 0.0038 & 0.0831 & 4.0029 & 54 \\
\hline$€ / ¥$ & -0.00022 & 0.0055 & 0.3238 & 4.4597 & 133 \\
\hline$€ / \mathrm{CHF}$ & $-6.50 \mathrm{E}-05$ & 0.0021 & 0.3025 & 4.2286 & 98 \\
\hline \multicolumn{6}{|c|}{ GERMANY } \\
\hline$€ / \$$ & 0.000302 & 0.0058 & -0.1429 & 3.4419 & 14 \\
\hline$€ / £$ & $5.99 \mathrm{E}-05$ & 0.0038 & 0.0831 & 4.0029 & 54 \\
\hline$€ / ¥$ & -0.00022 & 0.0055 & 0.3238 & 4.4597 & 133 \\
\hline$€ / \mathrm{CHF}$ & $-6.50 \mathrm{E}-05$ & 0.0021 & 0.3025 & 4.2286 & 98 \\
\hline \multicolumn{6}{|l|}{ ITALY } \\
\hline$€ / \$$ & 0.000302 & 0.0058 & -0.1429 & 3.4419 & 14 \\
\hline$€ / £$ & $5.99 \mathrm{E}-05$ & 0.0038 & 0.0831 & 4.0029 & 54 \\
\hline$€ / \#$ & -0.00022 & 0.0055 & 0.3238 & 4.4597 & 133 \\
\hline$€ / \mathrm{CHF}$ & $-6.50 \mathrm{E}-05$ & 0.0021 & 0.3025 & 4.2286 & 98 \\
\hline \multicolumn{6}{|l|}{ JAPAN } \\
\hline$¥ / €$ & 0.000219 & 0.0055 & -0.3238 & 4.4597 & 133 \\
\hline$¥ / \$$ & $-8.62 \mathrm{E}-05$ & 0.0059 & -0.2830 & 4.5441 & 136 \\
\hline$¥ / £$ & 0.000167 & 0.0057 & -0.5124 & 5.2745 & 314 \\
\hline$¥ / \mathrm{CHF}$ & 0.000164 & 0.0091 & -0.2452 & 3.4915 & 24 \\
\hline \multicolumn{6}{|l|}{ UK } \\
\hline$£ / €$ & -0.00026 & 0.0054 & 0.1466 & 4.0860 & 62 \\
\hline$£ / \$$ & -0.00026 & 0.0054 & 0.0839 & 4.0850 & 59 \\
\hline 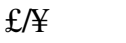 & -0.00021 & 0.0089 & 0.0092 & 4.2362 & 75 \\
\hline$£ / C H F$ & -0.00018 & 0.0087 & 0.1027 & 3.3903 & 9 \\
\hline \multicolumn{6}{|l|}{ US } \\
\hline$\$ / €$ & -0.0003 & 0.005794 & 0.141897 & 3.4401 & 14 \\
\hline$\$ / £$ & 0.000244 & 0.005221 & -0.12246 & 3.6344 & 24 \\
\hline$\$ / \#$ & $8.31 \mathrm{E}-05$ & 0.005858 & 0.330416 & 4.5867 & 154 \\
\hline$\$ / \mathrm{CHF}$ & 0.000236 & 0.006529 & -0.03263 & 3.4612 & 11 \\
\hline
\end{tabular}


Table 6 Augmented Dickey-Fuller Test Results

\begin{tabular}{|c|c|c|c|}
\hline & 1996-1998 & 1999-2001 & $2002-2006$ \\
\hline \multicolumn{4}{|l|}{ Stock Returns } \\
\hline S\&P/TSX Composite & $-6.36 *$ & $-19.91 *$ & $-34.10 *$ \\
\hline CAC 40 & $-9.05^{*}$ & $-26.47 *$ & $-9.79 *$ \\
\hline DAX 30 & $-6.55^{*}$ & $-27.13 *$ & $-8.53 *$ \\
\hline MIB 30 & $-16.68 *$ & $-11.95 *$ & $-13.64 *$ \\
\hline NIKKEI 225 & $-21.84 *$ & $-28.30 *$ & $-13.62 *$ \\
\hline FTSE 100 & $-7.02 *$ & $-17.68 *$ & $-11.89 *$ \\
\hline Dow Jones & $-27.14 *$ & $-20.50 *$ & $-8.48 *$ \\
\hline \multicolumn{4}{|l|}{ Exchange Rates } \\
\hline \multicolumn{4}{|l|}{ CANADA } \\
\hline $\mathrm{C} \$ / \$$ & $-13.75^{*}$ & $\mathrm{n} / \mathrm{a}$ & $\mathrm{n} / \mathrm{a}$ \\
\hline $\mathrm{C} \$ / £$ & $-19.72 *$ & $\mathrm{n} / \mathrm{a}$ & $\mathrm{n} / \mathrm{a}$ \\
\hline $\mathrm{C} \$ / ¥$ & $-11.56^{*}$ & $\mathrm{n} / \mathrm{a}$ & $\mathrm{n} / \mathrm{a}$ \\
\hline $\mathrm{C} \$ / \mathrm{CHF}$ & $-26.82 *$ & $\mathrm{n} / \mathrm{a}$ & $\mathrm{n} / \mathrm{a}$ \\
\hline $\mathrm{C} \$ / \mathrm{DM}$ & $-27.00 *$ & $\mathrm{n} / \mathrm{a}$ & $\mathrm{n} / \mathrm{a}$ \\
\hline \multicolumn{4}{|l|}{ FRANCE } \\
\hline FRANCS/\$ & $-27.26^{*}$ & $\mathrm{n} / \mathrm{a}$ & $\mathrm{n} / \mathrm{a}$ \\
\hline FRANCS/£ & $-27.90 *$ & $\mathrm{n} / \mathrm{a}$ & $\mathrm{n} / \mathrm{a}$ \\
\hline FRANCS/¥ & $-25.11 *$ & $\mathrm{n} / \mathrm{a}$ & $\mathrm{n} / \mathrm{a}$ \\
\hline FRANCS/CHF & $-26.59 *$ & $\mathrm{n} / \mathrm{a}$ & $\mathrm{n} / \mathrm{a}$ \\
\hline FRANCS/DM & $-24.45 *$ & $\mathrm{n} / \mathrm{a}$ & $\mathrm{n} / \mathrm{a}$ \\
\hline \multicolumn{4}{|l|}{ GERMANY } \\
\hline $\mathrm{DM} / \$$ & $-10.57 *$ & $\mathrm{n} / \mathrm{a}$ & $\mathrm{n} / \mathrm{a}$ \\
\hline $\mathrm{DM} / £$ & $-10.79 *$ & $\mathrm{n} / \mathrm{a}$ & $\mathrm{n} / \mathrm{a}$ \\
\hline $\mathrm{DM} / ¥$ & $-26.54 *$ & $\mathrm{n} / \mathrm{a}$ & $\mathrm{n} / \mathrm{a}$ \\
\hline $\mathrm{DM} / \mathrm{CHF}$ & $-11.04 *$ & $\mathrm{n} / \mathrm{a}$ & $\mathrm{n} / \mathrm{a}$ \\
\hline \multicolumn{4}{|l|}{ ITALY } \\
\hline Lira/\$ & $-27.28 *$ & $\mathrm{n} / \mathrm{a}$ & $\mathrm{n} / \mathrm{a}$ \\
\hline Lira/£ & $-15.45^{*}$ & $\mathrm{n} / \mathrm{a}$ & $\mathrm{n} / \mathrm{a}$ \\
\hline Lira/¥ & $-25.26 *$ & $\mathrm{n} / \mathrm{a}$ & $\mathrm{n} / \mathrm{a}$ \\
\hline Lira/CHF & $-20.34 *$ & $\mathrm{n} / \mathrm{a}$ & $\mathrm{n} / \mathrm{a}$ \\
\hline Lira/DM & $-29.39 *$ & $\mathrm{n} / \mathrm{a}$ & $\mathrm{n} / \mathrm{a}$ \\
\hline \multicolumn{4}{|l|}{ JAPAN } \\
\hline$¥ / €$ & $\mathrm{n} / \mathrm{a}$ & $-26.54 *$ & $-14.21 *$ \\
\hline$¥ / \$$ & $-7.00^{*}$ & $-27.48 *$ & $-35.81 *$ \\
\hline$¥ / £$ & $-11.43 *$ & $-26.23 *$ & $-12.42 *$ \\
\hline$¥ / \mathrm{CHF}$ & $-25.69 *$ & $-29.21 *$ & $-21.28 *$ \\
\hline$¥ / \mathrm{DM}$ & $-25.30 *$ & $\mathrm{n} / \mathrm{a}$ & $\mathrm{n} / \mathrm{a}$ \\
\hline \multicolumn{4}{|l|}{ UK } \\
\hline$£ / €$ & $\mathrm{n} / \mathrm{a}$ & $-25.74 *$ & $-33.28 *$ \\
\hline$£ / \$$ & $-26.39 *$ & $-26.18 *$ & $-33.82 *$ \\
\hline$£ / ¥$ & $-11.43 *$ & $-16.55^{*}$ & $-35.06 *$ \\
\hline$£ / \mathrm{CHF}$ & $-27.29 *$ & $-24.96 *$ & $-34.11 *$ \\
\hline$£ / D M$ & $-15.17 *$ & $\mathrm{n} / \mathrm{a}$ & $\mathrm{n} / \mathrm{a}$ \\
\hline \multicolumn{4}{|l|}{ US } \\
\hline$\$ / €$ & $\mathrm{n} / \mathrm{a}$ & $-10.54 *$ & $-6.72 *$ \\
\hline$\$ / £$ & $-26.39 *$ & $-13.30 *$ & $-34.85^{*}$ \\
\hline$\$ / ¥$ & $-7.00 *$ & $-28.26^{*}$ & $-36.33^{*}$ \\
\hline \$/CHF & $-26.70 *$ & $-26.86 *$ & $-37.84 *$ \\
\hline$\$ / \mathrm{DM}$ & $-27.28 *$ & $\mathrm{n} / \mathrm{a}$ & $\mathrm{n} / \mathrm{a}$ \\
\hline
\end{tabular}

Note: * Indicates significant at $1 \%$ level 
Table 7 Augmented Dickey-Fuller Test Results: Post Euro

\begin{tabular}{|c|c|c|}
\hline & 1999-2001 & 2002-2006 \\
\hline \multicolumn{3}{|c|}{ Exchange Rates } \\
\hline \multicolumn{3}{|c|}{ CANADA } \\
\hline $\mathrm{C} \$ / €$ & $-25.26 *$ & $-34.07 *$ \\
\hline $\mathrm{C} \$ / \$$ & $-12.53^{*}$ & $-35.34 *$ \\
\hline $\mathrm{C} \$ / £$ & $-27.57 *$ & $-33.82 *$ \\
\hline $\mathrm{C} \$ ¥ ¥$ & $-28.01 *$ & $-28.90 *$ \\
\hline $\mathrm{C} \$ / \mathrm{CHF}$ & $-27.30 *$ & $-23.27 *$ \\
\hline \multicolumn{3}{|c|}{ FRANCE } \\
\hline$€ / \$$ & $-10.57 *$ & $-6.73 *$ \\
\hline$€ / £$ & $-10.79 *$ & $-17.64 *$ \\
\hline$€ / ¥$ & $-26.54 *$ & $-14.21 *$ \\
\hline$€ / \mathrm{CHF}$ & $-11.04 *$ & $-35.70 *$ \\
\hline$€ / \$$ & $-10.57 *$ & $-6.73 *$ \\
\hline \multicolumn{3}{|c|}{ GERMANY } \\
\hline$€ / \$$ & $-10.57 *$ & $-6.73 *$ \\
\hline$€ / £$ & $-10.79 *$ & $-17.64 *$ \\
\hline$€ / ¥$ & $-26.54 *$ & $-14.21 *$ \\
\hline$€ / \mathrm{CHF}$ & $-11.04 *$ & $-35.70 *$ \\
\hline \multicolumn{3}{|l|}{ ITALY } \\
\hline$€ / \$$ & $-10.57 *$ & $-6.73 *$ \\
\hline$€ / £$ & $-10.79 *$ & $-17.64 *$ \\
\hline$€ / ¥$ & $-26.54 *$ & $-14.21 *$ \\
\hline$€ / \mathrm{CHF}$ & $-11.04 *$ & $-35.70 *$ \\
\hline
\end{tabular}

Note: * Indicates significant at $1 \%$ level 


\begin{tabular}{|c|c|c|c|c|c|}
\hline Canada & & & & & \\
\hline 1996-1998 & $\mathrm{C} \$ \mathbf{\$}$ & $\mathrm{C} \$ / £$ & $\mathrm{C} \$ \mathbf{I}$ & $\mathrm{C} / \mathrm{CHF}$ & C\$/DM \\
\hline Stock Returns & 0.256 & 0.336 & 0.06 & 0.398 & 0.18 \\
\hline Exchange Rates & 0.48 & 0.044 & 0.97 & 0.781 & $18.317 *$ \\
\hline 1999-2001 & $\mathrm{C} \$ / €$ & $\mathrm{C} \$ \mathbf{\$}$ & $\mathrm{C} \$ / £$ & $\mathrm{C} \$ / ¥$ & $\mathrm{C} \$ \mathrm{CHF}$ \\
\hline Stock Returns & 12.084 & 11.238 & $9.998 *$ & $10.868 *$ & $10.11 *$ \\
\hline Exchange Rates & 0.057 & 1.258 & 0.152 & 0.794 & 0.19 \\
\hline 2002-2006 & $\mathrm{C} \$ / €$ & $\mathrm{C} \$ \mathbf{\$}$ & $\mathrm{C} \$ / £$ & $\mathrm{C} \$ \mathbf{I}$ & $\mathrm{C} \$ \mathrm{CHF}$ \\
\hline Stock Returns & 0.402 & 0.246 & 0.612 & 0.29 & 0.210 \\
\hline Exchange Rates & 0 & 0.656 & $7.38 *$ & 0.07 & 0.016 \\
\hline \multicolumn{6}{|l|}{ France } \\
\hline 1996-1998 & FR/\$ & FR/£ & FR/ $¥$ & FR/CHF & FR/DM \\
\hline Stock Returns & 1.364 & 0.922 & 1.142 & 1.458 & 0.084 \\
\hline Exchange Rates & 16.93 & 3.84 & 1.912 & 3.594 & $14.84 *$ \\
\hline 1999-2001 & $€ / \$$ & $€ / \mathfrak{f}$ & $€ / ¥$ & $€ / C H F$ & \\
\hline Stock Returns & 0.2022 & 0.0728 & 0.195 & 0.488 & \\
\hline Exchange Rates & 2.28 & 0.492 & 1.092 & 0.022 & \\
\hline 2002-2006 & $€ / \$$ & $€ / £$ & $€ / ¥$ & $€ / C H F$ & \\
\hline Stock Returns & $7.706^{*}$ & 7.256 & $6.908^{*}$ & 2.734 & \\
\hline Exchange Rates & $7.8488 *$ & 0.056 & 0.756 & 0.0256 & \\
\hline \multicolumn{6}{|l|}{ Germany } \\
\hline 1996-1998 & DM/\$ & DM/£ & $\mathbf{D M} / ¥$ & DM/CHF & \\
\hline Stock Returns & 1.386 & $8.046^{*}$ & 5.64 & 6.142 & \\
\hline Exchange Rates & $16.602 *$ & 2.99 & 2.718 & 6.158 & \\
\hline 1999-2001 & $€ / \$$ & 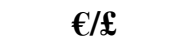 & $€ / ¥$ & $€ / C H F$ & \\
\hline Stock Returns & $12.441 *$ & $12.02 *$ & $14.864 *$ & $11.568 *$ & \\
\hline Exchange Rates & 1.738 & 0.592 & 1.574 & 0.048 & \\
\hline 2002-2006 & $€ / \$$ & $€ / £$ & $€ / ¥$ & $€ / C H F$ & \\
\hline Stock Returns & 5.852 & 5.68 & $15.92 *$ & 4.484 & \\
\hline Exchange Rates & 4.205 & 0.086 & 0.8 & 0.1006 & \\
\hline \multicolumn{6}{|l|}{ Italy } \\
\hline 1996-1998 & LIRA/\$ & LIRA/£ & LIRA/¥ & LIRA/CHF & LIRA/DM \\
\hline Stock Returns & 1.56 & 2.12 & 2.11 & 1.94 & 3.81 \\
\hline Exchange Rates & 4.95 & 0.13 & 0.25 & 2.49 & 5.52 \\
\hline 1999-2001 & $€ / \$$ & $€ / £$ & $€ / ¥$ & $€ / \mathbf{C H F}$ & \\
\hline Stock Returns & 0.238 & 0.507 & 1.192 & 1.77 & \\
\hline Exchange Rates & 1.962 & 0.414 & 3.092 & 0.916 & \\
\hline 2002-2006 & $€ / \$$ & $€ / £$ & $€ / ¥$ & $€ / C H F$ & \\
\hline Stock Returns & 1.42 & 1.158 & 1.432 & 0.372 & \\
\hline Exchange Rates & $38.155^{*}$ & 0.14 & 1.058 & 0.042 & \\
\hline \multicolumn{6}{|l|}{ Japan } \\
\hline 1996-1998 & $¥ / \$$ & $¥ / £$ & $¥ / \mathrm{CHF}$ & $¥ / \mathbf{D M}$ & \\
\hline Stock Returns & 0.056 & 0.206 & 0.204 & 0.254 & \\
\hline Exchange Rates & 0.284 & 1.664 & $17.536^{*}$ & 4.994 & \\
\hline 1999-2001 & $¥ / €$ & $¥ / \$$ & $¥ / £$ & $¥ / \mathbf{C H F}$ & \\
\hline Stock Returns & $13.73 *$ & $13.746^{*}$ & $14.554 *$ & $12.384 *$ & \\
\hline Exchange Rates & 3.66 & 2.718 & 1.118 & 1.026 & \\
\hline 2002-2006 & $¥ / €$ & $¥ / \$$ & $¥ / £$ & $¥ / \mathrm{CHF}$ & \\
\hline Stock Returns & $11.028 *$ & $10.152 *$ & $10.284 *$ & $11.32 *$ & \\
\hline Exchange Rates & 2.266 & 2.142 & 4.073 & 3.78 & \\
\hline \multicolumn{6}{|l|}{ UK } \\
\hline 1996-1998 & $\mathfrak{f} / \$$ & $\mathfrak{E} / ¥$ & $£ / C H F$ & $\mathfrak{f} / \mathbf{D M}$ & \\
\hline Stock Returns & 1.28 & 1.94 & 1.27 & 1.286 & \\
\hline Exchange Rates & 1.76 & 3.35 & 5.47 & 1.76 & \\
\hline 1999-2001 & $\mathfrak{£} / €$ & $£ / \$$ & $\mathfrak{£} ¥$ & $£ / C H F$ & \\
\hline Stock Returns & 0.061 & 2.591 & 0.131 & 0.01 & \\
\hline Exchange Rates & 0.453 & 0.01 & 0.276 & 0.002 & \\
\hline 2002-2006 & $\mathfrak{£ / € ~}$ & $\mathfrak{f} / \$$ & $\mathfrak{£} / ¥$ & $\mathfrak{f} / \mathbf{C H F}$ & \\
\hline
\end{tabular}




\begin{tabular}{|c|c|c|c|c|}
\hline Stock Returns & 1.376 & 1.12 & 0.762 & 0.292 \\
\hline $\begin{array}{c}\text { Exchange Rates } \\
\text { US }\end{array}$ & $33.848^{*}$ & 5.076 & 0.403 & $23.294 *$ \\
\hline 1996-1998 & $\$ / £$ & \$/¥ & \$/CHF & \$/DM \\
\hline Stock Returns & $6.892 *$ & $6.612 *$ & 5.706 & $6.934 *$ \\
\hline Exchange Rates & 3.608 & 0.006 & 1.022 & 4.783 \\
\hline 1999-2001 & $\$ / €$ & $\$ / £$ & $\$ / ¥$ & \$/CHF \\
\hline Stock Returns & 0 & 0.088 & 0.102 & 0.004 \\
\hline Exchange Rates & 1.132 & 0.401 & 1.932 & 2.324 \\
\hline 2002-2006 & $\$ / €$ & $\$ / £$ & $\$ / ¥$ & $\$ / \mathrm{CHF}$ \\
\hline Stock Returns & 5.202 & 4.946 & 3.202 & 5.382 \\
\hline Exchange Rates & $43.93 *$ & $43.012 *$ & 0.693 & 5.969 \\
\hline
\end{tabular}

Note: $\mathrm{H}_{0}$ : $\operatorname{EGARCH}(1,1), \mathrm{H}_{1}: \operatorname{EGARCH}(2,1)$ The $5 \%$ critical value for the $\mathrm{LR}$ test distributed as $\chi^{2}$ with 2 degrees of freedom is 5.99. Note: * Indicates significant at $1 \%$ level 
Table 9 EGARCH RESULTS VOLATILITY PERSISTENCE 1996-1998

\begin{tabular}{|c|c|c|c|c|c|}
\hline Canada & $\mathrm{C} \$ / \$$ & $\mathrm{C} \$ / ¥$ & C\$/DM & C $\$ / C H F$ & $\mathrm{C} \$ / \mathfrak{f}$ \\
\hline \multirow[t]{2}{*}{ Stock Returns } & 0.2749 & 0.2083 & 0.2766 & 0.2706 & 0.2828 \\
\hline & $(0.000)$ & $(0.000)$ & $(0.000)$ & $(0.000)$ & $(0.000)$ \\
\hline \multirow[t]{2}{*}{ Exchange Rates } & 0.1335 & 0.2671 & 0.2173 & 0.1132 & 0.0866 \\
\hline & $(0.004)$ & $(0.002)$ & $(0.004)$ & $(0.038)$ & $(0.005)$ \\
\hline France & FR/\$ & FR/£ & FR/ $¥$ & FR/CHF & FR/DM \\
\hline \multirow[t]{2}{*}{ Stock Returns } & 0.1279 & 0.1314 & 0.1270 & 0.1278 & 0.1322 \\
\hline & $(0.000)$ & $(0.000)$ & $(0.000)$ & $(0.000)$ & $(0.000)$ \\
\hline \multirow[t]{2}{*}{ Exchange Rates } & 0.0171 & 0.0569 & 0.1826 & 0.0436 & 0.6480 \\
\hline & $(0.837)$ & $(0.0386)$ & $(0.000)$ & $(0.088)$ & $(0.000)$ \\
\hline Germany & $\mathrm{DM} / \$$ & $\mathrm{DM} / \mathfrak{£}$ & DM/¥ & DM/CHF & \\
\hline \multirow[t]{2}{*}{ Stock Returns } & 0.1345 & -0.0596 & 0.1538 & -0.0314 & \\
\hline & $(0.000)$ & $(0.4952)$ & $(0.000)$ & $(0.7285)$ & \\
\hline \multirow[t]{2}{*}{ Exchange Rates } & -0.1973 & -0.1532 & -0.1936 & -0.1417 & \\
\hline & $(0.652)$ & $(0.026)$ & $(0.000)$ & $(0.0311)$ & \\
\hline Italy & LIRA/CHF & LIRA/\# & LIRA/DM & LIRA/£ & LIRA/\$ \\
\hline \multirow[t]{2}{*}{ Stock Returns } & 0.2081 & 0.2652 & 0.1914 & 0.2522 & 0.2534 \\
\hline & $(0.000)$ & $(0.000)$ & $(0.000)$ & $(0.000)$ & $(0.000)$ \\
\hline \multirow[t]{2}{*}{ Exchange Rates } & 0.0303 & 0.2463 & 0.1422 & 0.1098 & 0.1059 \\
\hline & $(0.207)$ & $(0.006)$ & $(0.000)$ & $(0.002)$ & $(0.003)$ \\
\hline Japan & $¥ / \$$ & $¥ / £$ & $¥ / \mathrm{CHF}$ & $¥ / \mathbf{D M}$ & \\
\hline \multirow{2}{*}{ Stock Returns } & 0.0450 & 0.0607 & 0.0528 & 0.0483 & \\
\hline & $(0.033)$ & $(0.008)$ & $(0.0130)$ & $(0.0215)$ & \\
\hline \multirow{2}{*}{ Exchange Rates } & 0.2261 & 0.2589 & 0.1903 & 0.1523 & \\
\hline & $(0.0235)$ & $(0.004)$ & $(0.093)$ & $(0.000)$ & \\
\hline UK & $\mathfrak{f} / \mathbf{\$}$ & $\mathfrak{f} / ¥$ & $£ / C H F$ & $\mathfrak{f} / \mathbf{D M}$ & \\
\hline \multirow[t]{2}{*}{ Stock Returns } & 0.0741 & 0.0851 & 0.0873 & 0.0862 & \\
\hline & $(0.002)$ & $(0.001)$ & $(0.001)$ & $(0.001)$ & \\
\hline \multirow[t]{2}{*}{ Exchange Rates } & -0.0017 & 0.2637 & 0.0549 & 0.0638 & \\
\hline & $(0.891)$ & $(0.002)$ & $(0.107)$ & $(0.017)$ & \\
\hline US & $\$ / \mathfrak{£}$ & $\$ / \#$ & \$/CHF & \$/DM & \\
\hline \multirow[t]{2}{*}{ Stock Returns } & -0.0332 & -0.0306 & 0.1396 & -0.0381 & \\
\hline & $(0.741)$ & $(0.760)$ & $(0.005)$ & $(0.723)$ & \\
\hline \multirow[t]{2}{*}{ Exchange Rates } & 0.0063 & 0.2147 & 0.0425 & -0.0863 & \\
\hline & $(0.647)$ & $(0.017)$ & $(0.570)$ & $(0.287)$ & \\
\hline
\end{tabular}


Table 10 EGARCH RESULTS VOLATILITY PERSISTENCE 1999-2001

\begin{tabular}{|c|c|c|c|c|c|}
\hline Canada & $\mathrm{C} \$ \mathbf{S}$ & $\mathrm{C} \$ / ¥$ & $\mathrm{C} \$ \mathrm{CHF}$ & $\mathrm{C} \$ / £$ & $\mathrm{C} \$ / €$ \\
\hline \multirow[t]{2}{*}{ Stock Returns } & -0.11603 & -0.1227 & -0.1101 & -0.1016 & -0.1172 \\
\hline & $(0.286)$ & $(0.237)$ & $(0.279)$ & $(0.327)$ & $(0.304)$ \\
\hline \multirow[t]{2}{*}{ Exchange Rates } & -0.1667 & 0.0292 & -0.0409 & 0.0959 & -0.0225 \\
\hline & $(0.159)$ & $(0.189)$ & $(0.274)$ & $(0.220)$ & $(0.746)$ \\
\hline France & $€ / \$$ & $€ / £$ & $€ / ¥$ & €/CHF & \\
\hline \multirow[t]{2}{*}{ Stock Returns } & 0.1021 & 0.0966 & 0.0978 & 0.0939 & \\
\hline & $(0.028)$ & $(0.042)$ & $(0.027)$ & $(0.041)$ & \\
\hline \multirow[t]{2}{*}{ Exchange Rates } & -0.1106 & 0.2804 & 0.1108 & 0.1558 & \\
\hline & $(0.072)$ & $(0.001)$ & $(0.068)$ & $(0.002)$ & \\
\hline Germany & $€ / \$$ & $€ / £$ & $€ / ¥$ & $€ / C H F$ & \\
\hline \multirow[t]{2}{*}{ Stock Returns } & -0.1973 & -0.1532 & -0.1936 & -0.1417 & \\
\hline & $(0.013)$ & $(0.080)$ & $(0.021)$ & $(0.109)$ & \\
\hline \multirow[t]{2}{*}{ Exchange Rates } & -0.1122 & 0.2794 & 0.0965 & 0.1614 & \\
\hline & $(0.103)$ & $(0.001)$ & $(0.092)$ & $(0.001)$ & \\
\hline Italy & €/CHF & $€ / ¥$ & $\boldsymbol{€} / £$ & $€ / \$$ & \\
\hline \multirow[t]{2}{*}{ Stock Returns } & 0.2301 & 0.2535 & 0.2627 & 0.2671 & \\
\hline & $(0.001)$ & $(0.000)$ & $(0.000)$ & $(0.000)$ & \\
\hline \multirow[t]{2}{*}{ Exchange Rates } & 0.1536 & 0.1058 & 0.2543 & -0.1050 & \\
\hline & $(0.003)$ & $(0.079)$ & $(0.003)$ & $(0.124)$ & \\
\hline Japan & $¥ / €$ & $¥ / \$$ & $¥ / £$ & $¥ / \mathrm{CHF}$ & \\
\hline \multirow[t]{2}{*}{ Stock Returns } & -0.1268 & -0.1209 & -0.1261 & -0.1059 & \\
\hline & $(0.2795)$ & $(0.272)$ & $(0.251)$ & $(0.085)$ & \\
\hline \multirow[t]{2}{*}{ Exchange Rates } & 0.0929 & 0.0430 & 0.0171 & -0.1059 & \\
\hline & $(0.097)$ & $(0.066)$ & $(0.503)$ & $(0.334)$ & \\
\hline UK & $£ / €$ & $\mathfrak{f} / \mathbf{\$}$ & $\mathfrak{£} / ¥$ & £/CHF & \\
\hline \multirow[t]{2}{*}{ Stock Returns } & 0.0691 & 0.0689 & 0.0599 & 0.0660 & \\
\hline & $(0.059)$ & $(0.106)$ & $(0.106)$ & $(0.073)$ & \\
\hline \multirow[t]{2}{*}{ Exchange Rates } & 0.0858 & 0.1377 & 0.1879 & 0.0728 & \\
\hline & $(0.211)$ & $(0.115)$ & $(0.000)$ & $(0.130)$ & \\
\hline US & $\$ / €$ & $\$ / £$ & $\$ / ¥$ & \$/CHF & \\
\hline \multirow[t]{2}{*}{ Stock Returns } & 0.0550 & 0.0860 & 0.0388 & 0.0540 & \\
\hline & $(0.147)$ & $(0.238)$ & $(0.292)$ & $(0.124)$ & \\
\hline \multirow[t]{2}{*}{ Exchange Rates } & -0.0537 & 0.0860 & 0.0516 & -0.0557 & \\
\hline & $(0.272)$ & $(0.238)$ & $(0.028)$ & $(0.458)$ & \\
\hline
\end{tabular}


Table 11 EGARCH RESULTS VOLATILITY PERSISTENCE 2002-2006

\begin{tabular}{|c|c|c|c|c|c|}
\hline Canada & $\mathrm{C} \$ / \$$ & $\mathrm{C} \$ / ¥$ & $\mathrm{C} \$ \mathrm{CHF}$ & $\mathrm{C} \$ / £$ & $\mathrm{C} \$ / €$ \\
\hline \multirow[t]{2}{*}{ Stock Returns } & 0.0886 & 0.0794 & 0.0821 & 0.0871 & 0.0981 \\
\hline & $(0.001)$ & $(0.004)$ & $(0.002)$ & $(0.002)$ & $(0.001)$ \\
\hline \multirow[t]{2}{*}{ Exchange Rates } & 0.1044 & 0.0548 & 0.1240 & 0.0371 & 0.0455 \\
\hline & $(0.014)$ & $(0.044)$ & $(0.000)$ & $(0.597)$ & $(0.386)$ \\
\hline France & $€ / \$$ & $€ / £$ & $€ / ¥$ & $€ / \mathrm{CHF}$ & \\
\hline \multirow[t]{2}{*}{ Stock Returns } & -0.0568 & -0.0618 & -0.0672 & 0.0947 & \\
\hline & $(0.492)$ & $(0.417)$ & $(0.406)$ & $(0.000)$ & \\
\hline \multirow[t]{2}{*}{ Exchange Rates } & -0.1165 & 0.0402 & 0.0466 & 0.0957 & \\
\hline & $(0.115)$ & $(0.005)$ & $(0.029)$ & $(0.001)$ & \\
\hline Germany & $€ / \$$ & $€ / £$ & $€ / ¥$ & $€ / \mathrm{CHF}$ & \\
\hline \multirow[t]{2}{*}{ Stock Returns } & 0.1116 & 0.1063 & -0.0230 & 0.1035 & \\
\hline & $(0.000)$ & $(0.000)$ & $(0.781)$ & $(0.000)$ & \\
\hline \multirow[t]{2}{*}{ Exchange Rates } & 0.0596 & 0.0377 & 0.0459 & 0.0914 & \\
\hline & $(0.005)$ & $(0.008)$ & $(0.036)$ & $(0.002)$ & \\
\hline Italy & $€ / \mathrm{CHF}$ & $€ / ¥$ & $\boldsymbol{€} / £$ & $€ / \$$ & \\
\hline \multirow[t]{2}{*}{ Stock Returns } & 0.0660 & 0.0774 & 0.0741 & 0.0832 & \\
\hline & $(0.000)$ & $(0.000)$ & $(0.000)$ & $(0.000)$ & \\
\hline \multirow[t]{2}{*}{ Exchange Rates } & 0.0919 & 0.0488 & 0.0447 & -0.0934 & \\
\hline & $(0.001)$ & $(0.029)$ & $(0.002)$ & $(0.209)$ & \\
\hline Japan & $¥ / €$ & $¥ / \$$ & $¥ / £$ & $¥ / \mathrm{CHF}$ & \\
\hline \multirow[t]{2}{*}{ Stock Returns } & -0.0693 & -0.0437 & -0.0461 & -0.0606 & \\
\hline & $(0.359)$ & $(0.581)$ & $(0.555)$ & $(0.442)$ & \\
\hline \multirow[t]{2}{*}{ Exchange Rates } & 0.0491 & -0.0040 & 0.0942 & 0.1363 & \\
\hline & $(0.019)$ & $(0.962)$ & $(0.259)$ & $(0.007)$ & \\
\hline UK & $\mathfrak{£} / €$ & $\mathfrak{f} / \mathbf{\$}$ & $\mathfrak{£} / ¥$ & £/CHF & \\
\hline \multirow[t]{2}{*}{ Stock Returns } & 0.0814 & 0.0883 & 0.0741 & 0.0720 & \\
\hline & $(0.000)$ & $(0.000)$ & $(0.000)$ & $(0.000)$ & \\
\hline \multirow[t]{2}{*}{ Exchange Rates } & 0.1052 & -0.0158 & 0.0226 & -0.0887 & \\
\hline & $(0.070)$ & $(0.131)$ & $(0.431)$ & $(0.233)$ & \\
\hline US & $\$ / €$ & $\$ / £$ & $\$ / ¥$ & \$/CHF & \\
\hline \multirow[t]{2}{*}{ Stock Returns } & 0.0663 & 0.0654 & 0.0585 & 0.0664 & \\
\hline & $(0.000)$ & $(0.000)$ & $(0.001)$ & $(0.000)$ & \\
\hline \multirow[t]{2}{*}{ Exchange Rates } & -0.0843 & 0.1561 & 0.0136 & 0.0544 & \\
\hline & $(0.254)$ & $(0.007)$ & $(0.873)$ & $(0.007)$ & \\
\hline
\end{tabular}


Table 12 EGARCH RESULTS VOLATILITY SPILLOVERS 1996-1998

\begin{tabular}{|c|c|c|c|c|c|}
\hline Canada & $\mathrm{C} \$ \mathbf{\$}$ & $\mathrm{C} \$ / ¥$ & C\$/DM & C\$/CHF & 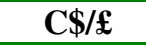 \\
\hline \multirow{2}{*}{ Stock Returns } & -0.1079 & -0.0585 & -0.0998 & -0.0987 & -0.0954 \\
\hline & $(0.005)$ & $(0.023)$ & $(0.010)$ & $(0.010)$ & $(0.008)$ \\
\hline \multirow{2}{*}{ Exchange Rates } & 0.0147 & 0.0834 & 0.0744 & 0.0458 & 0.0583 \\
\hline & $(0.577)$ & $(0.067)$ & $(0.145)$ & $(0.356)$ & $(0.121)$ \\
\hline France & FR/\$ & FR/£ & FR/ $¥$ & FR/CHF & FR/DM \\
\hline \multirow{2}{*}{ Stock Returns } & -0.0531 & -0.0655 & -0.0599 & -0.0635 & -0.0688 \\
\hline & $(0.017)$ & $(0.003)$ & $(0.010)$ & $(0.003)$ & $(0.002)$ \\
\hline \multirow{2}{*}{ Exchange Rates } & -0.0309 & 0.0270 & 0.0208 & 0.0265 & 0.1147 \\
\hline & $(0.537)$ & $(0.117)$ & $(0.558)$ & $(0.229)$ & $(0.018)$ \\
\hline Germany & DM/\$ & DM/£ & DM/¥ & DM/CHF & \\
\hline \multirow{2}{*}{ Stock Returns } & -0.0339 & -0.0750 & -0.0494 & -0.0603 & \\
\hline & $(0.170)$ & $(0.005)$ & $(0.040)$ & $(0.018)$ & \\
\hline \multirow{2}{*}{ Exchange Rates } & -0.0367 & 0.0176 & 0.0128 & 0.0362 & \\
\hline & $(0.441)$ & $(0.247)$ & $(0.716)$ & $(0.255)$ & \\
\hline Italy & Lira/\$ & Lira/£ & Lira/¥ & Lira/CHF & Lira/DM \\
\hline \multirow{2}{*}{ Stock Returns } & -0.0204 & -0.0376 & -0.0141 & -0.0341 & -0.0376 \\
\hline & $(0.495)$ & $(0.303)$ & $(0.627)$ & $(0.327)$ & $(0.290)$ \\
\hline \multirow{2}{*}{ Exchange Rates } & -0.0195 & 0.0601 & 0.0162 & 0.0174 & 0.0121 \\
\hline & $(0.074)$ & $(0.157)$ & $(0.577)$ & $(0.419)$ & $(0.692)$ \\
\hline Japan & $¥ / \$$ & $¥ / £$ & $¥ / \mathrm{CHF}$ & ¥/DM & \\
\hline \multirow{2}{*}{ Stock Returns } & -0.1320 & -0.1324 & -0.1364 & -0.1416 & \\
\hline & $(0.000)$ & $(0.000)$ & $(0.000)$ & $(0.000)$ & \\
\hline \multirow{2}{*}{ Exchange Rates } & -0.0586 & -0.0587 & -0.1899 & -0.0116 & \\
\hline & (0.1997) & $(0.307)$ & $(0.005)$ & $(0.736)$ & \\
\hline UK & $£ / \$$ & $£ / ¥$ & $£ / C H F$ & $\mathfrak{f} / \mathbf{D M}$ & \\
\hline \multirow{2}{*}{ Stock Returns } & -0.0516 & -0.0653 & -0.0596 & -0.0629 & \\
\hline & $(0.000)$ & $(0.000)$ & $(0.000)$ & $(0.000)$ & \\
\hline \multirow{2}{*}{ Exchange Rates } & -0.0402 & 0.0580 & -0.0063 & -0.0136 & \\
\hline & $(0.035)$ & $(0.304)$ & $(0.686)$ & $(0.352)$ & \\
\hline $\mathbf{U S}$ & $\$ / £$ & $\$ / ¥$ & \$/CHF & \$/DM & \\
\hline \multirow{2}{*}{ Stock Returns } & -0.1577 & -0.1601 & -0.1363 & -0.1583 & \\
\hline & $(0.000)$ & $(0.000)$ & $(0.000)$ & $(0.000)$ & \\
\hline \multirow{2}{*}{ Exchange Rates } & 0.0493 & 0.0392 & 0.0904 & -0.0332 & \\
\hline & $(0.019)$ & $(0.384)$ & $(0.072)$ & $(0.506)$ & \\
\hline
\end{tabular}


Table 13 EGARCH RESULTS VOLATILITY SPILLOVERS 1999-2001

\begin{tabular}{|c|c|c|c|c|c|}
\hline Canada & $\mathrm{C} \$ / \$$ & $\mathrm{C} \$ / ¥$ & $\mathrm{C} \$ \mathrm{CHF}$ & $\mathrm{C} \$ / £$ & $\mathrm{C} \$ / €$ \\
\hline \multirow{2}{*}{ Stock Returns } & -0.1014 & -0.1031 & -0.1078 & -0.1093 & -0.0619 \\
\hline & $(0.000)$ & $(0.000)$ & $(0.000)$ & $(0.000)$ & $(0.029)$ \\
\hline \multirow{2}{*}{ Exchange Rates } & -0.0693 & 0.0252 & -0.0054 & 0.0244 & 0.0180 \\
\hline & $(0.259)$ & $(0.117)$ & $(0.794)$ & $(0.556)$ & $(0.743)$ \\
\hline France & $€ / \$$ & $€ / £$ & $€ / ¥$ & $€ / \mathrm{CHF}$ & \\
\hline \multirow{2}{*}{ Stock Returns } & -0.0954 & -0.0805 & -0.0806 & -0.0671 & \\
\hline & $(0.002)$ & $(0.009)$ & $(0.011)$ & $(0.024)$ & \\
\hline \multirow{2}{*}{ Exchange Rates } & -0.0210 & -0.0753 & 0.0824 & 0.1331 & \\
\hline & $(0.639)$ & $(0.255)$ & $(0.008)$ & $(0.008)$ & \\
\hline Germany & $€ / \$$ & $\boldsymbol{€} / £$ & $€ / ¥$ & $€ / C H F$ & \\
\hline \multirow{2}{*}{ Stock Returns } & -0.1217 & -0.1131 & -0.1106 & -0.1075 & \\
\hline & $(0.001)$ & $(0.002)$ & $(0.002)$ & $(0.002)$ & \\
\hline \multirow{2}{*}{ Exchange Rates } & -0.0158 & -0.0800 & 0.0665 & 0.1333 & \\
\hline & $(0.723)$ & $(0.232)$ & $(0.023)$ & $(0.008)$ & \\
\hline Italy & $€ / \mathrm{CHF}$ & $€ / ¥$ & $\boldsymbol{€} / £$ & $€ / \$$ & \\
\hline \multirow{2}{*}{ Stock Returns } & -0.0815 & -0.0928 & -0.0961 & -0.1009 & \\
\hline & $(0.002)$ & $(0.018)$ & $(0.011)$ & $(0.008)$ & \\
\hline \multirow{2}{*}{ Exchange Rates } & -0.1292 & -0.0770 & -0.0793 & -0.0143 & \\
\hline & $(0.011)$ & $(0.013)$ & $(0.229)$ & $(0.745)$ & \\
\hline Japan & $¥ / €$ & $¥ / \$$ & $¥ / £$ & ¥/CHF & \\
\hline \multirow{2}{*}{ Stock Returns } & -0.0939 & -0.0896 & -0.0894 & -0.0840 & \\
\hline & $(0.0505)$ & $(0.004)$ & $(0.004)$ & $(0.001)$ & \\
\hline \multirow{2}{*}{ Exchange Rates } & -0.0617 & -0.0349 & -0.0242 & -0.0840 & \\
\hline & $(0.031)$ & $(0.094)$ & $(0.3777)$ & $(0.006)$ & \\
\hline UK & $£ / €$ & $\mathfrak{f} / \mathbf{\$}$ & $\mathfrak{£} / \mathbf{z}$ & £/CHF & \\
\hline \multirow{2}{*}{ Stock Returns } & -0.1015 & -0.1166 & -0.1117 & -0.1101 & \\
\hline & $(0.052)$ & $(0.035)$ & $(0.041)$ & $(0.039)$ & \\
\hline \multirow{2}{*}{ Exchange Rates } & -0.1385 & -0.0556 & -0.0024 & 0.0515 & \\
\hline & $(0.002)$ & $(0.227)$ & $(0.956)$ & $(0.073)$ & \\
\hline $\mathbf{U S}$ & $\$ / €$ & $\$ / £$ & $\$ / ¥$ & \$/CHF & \\
\hline \multirow{2}{*}{ Stock Returns } & -0.1372 & 0.0740 & -0.1324 & -0.1306 & \\
\hline & $(0.000)$ & $(0.0831)$ & $(0.000)$ & $(0.000)$ & \\
\hline \multirow{2}{*}{ Exchange Rates } & 0.0270 & 0.0740 & 0.0323 & -0.0004 & \\
\hline & $(0.560)$ & $(0.083)$ & $(0.136)$ & $(0.989)$ & \\
\hline
\end{tabular}


Table 14 EGARCH RESULTS VOLATILITY SPILLOVERS 2002-2006

\begin{tabular}{|c|c|c|c|c|c|}
\hline Canada & $\mathrm{C} \$ \mathbf{S}$ & $\mathrm{C} \$ / ¥$ & $\mathrm{C} \$ / \mathrm{CHF}$ & $\mathrm{C} \$ / \mathfrak{f}$ & $\mathrm{C} \$ / €$ \\
\hline \multirow{2}{*}{ Stock Returns } & -0.0803 & -0.0850 & -0.0836 & -0.0833 & -0.0939 \\
\hline & $(0.000)$ & $(0.000)$ & $(0.000)$ & $(0.000)$ & $(0.000)$ \\
\hline \multirow{2}{*}{ Exchange Rates } & -0.0081 & -0.0104 & 0.0073 & 0.0145 & 0.0977 \\
\hline & $(0.656)$ & $(0.657)$ & $(0.751)$ & $(0.012)$ & $(0.097)$ \\
\hline France & $€ / \$$ & $€ / £$ & $€ / ¥$ & $€ / C H F$ & \\
\hline \multirow{2}{*}{ Stock Returns } & -0.1149 & -0.1304 & -0.1156 & -0.1297 & \\
\hline & $(0.000)$ & $(0.000)$ & $(0.000)$ & $(0.000)$ & \\
\hline \multirow{2}{*}{ Exchange Rates } & 0.0032 & 0.0043 & 0.0032 & -0.0023 & \\
\hline & $(0.814)$ & $(0.727)$ & $(0.863)$ & $(0.925)$ & \\
\hline Germany & $€ / \$$ & $€ / £$ & $€ / ¥$ & $€ / \mathrm{CHF}$ & \\
\hline \multirow{2}{*}{ Stock Returns } & -0.0949 & -0.1109 & -0.1083 & -0.0991 & \\
\hline & $(0.000)$ & $(0.000)$ & $(0.000)$ & $(0.000)$ & \\
\hline \multirow{2}{*}{ Exchange Rates } & 0.0069 & 0.0053 & 0.0004 & -0.0041 & \\
\hline & $(0.571)$ & $(0.664)$ & $(0.982)$ & $(0.866)$ & \\
\hline Italy & $€ / \mathrm{CHF}$ & $€ / ¥$ & $\boldsymbol{€} / £$ & $€ / \$$ & \\
\hline \multirow{2}{*}{ Stock Returns } & -0.0983 & -0.0923 & -0.0996 & -0.0868 & \\
\hline & $(0.000)$ & $(0.000)$ & $(0.000)$ & $(0.000)$ & \\
\hline \multirow{2}{*}{ Exchange Rates } & 0.0022 & -0.0031 & 0.0035 & 0.0032 & \\
\hline & $(0.925)$ & $(0.867)$ & $(0.775)$ & $(0.799)$ & \\
\hline Japan & $¥ / €$ & $¥ / \$$ & 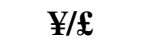 & $¥ / \mathrm{CHF}$ & \\
\hline \multirow{2}{*}{ Stock Returns } & -0.0506 & -0.0598 & -0.0595 & -0.0583 & \\
\hline & $(0.0477)$ & $(0.025)$ & $(0.026)$ & $(0.029)$ & \\
\hline \multirow{2}{*}{ Exchange Rates } & 0.0007 & 0.0241 & -0.1276 & -0.0055 & \\
\hline & $(0.971)$ & $(0.682)$ & $(0.033)$ & $(0.892)$ & \\
\hline UK & $\mathfrak{£} / €$ & $\mathfrak{f} / \mathbf{\$}$ & $\mathfrak{£} ¥ ¥$ & £/CHF & \\
\hline \multirow{2}{*}{ Stock Returns } & -0.1205 & -0.1189 & -0.1244 & -0.1278 & \\
\hline & $(0.000)$ & $(0.000)$ & $(0.000)$ & $(0.000)$ & \\
\hline \multirow{2}{*}{ Exchange Rates } & 0.0958 & -0.0340 & 0.0218 & -0.0024 & \\
\hline & $(0.041)$ & $(0.000)$ & $(0.2887)$ & $(0.757)$ & \\
\hline US & $\$ / €$ & $\$ / £$ & $\$ / ¥$ & \$/CHF & \\
\hline \multirow{2}{*}{ Stock Returns } & -0.0802 & -0.0810 & -0.0852 & -0.0777 & \\
\hline & $(0.000)$ & $(0.000)$ & $(0.000)$ & $(0.000)$ & \\
\hline \multirow{2}{*}{ Exchange Rates } & -0.0080 & -0.1030 & -0.0662 & -0.0035 & \\
\hline & $(0.494)$ & $(0.020)$ & $(0.272)$ & $(0.801)$ & \\
\hline
\end{tabular}


Table 15 EGARCH RESULTS ASYMMETRIC SPILLOVERS 1996-1998

\begin{tabular}{|c|c|c|c|c|c|}
\hline Canada & $\mathrm{C} \$ \mathbf{\$}$ & $\mathrm{C} \$ / ¥$ & C\$/DM & $\mathrm{C} / \mathrm{CHF}$ & $\mathrm{C} \$ / £$ \\
\hline \multirow{2}{*}{ Stock Returns } & 0.9642 & 0.9742 & 0.9665 & 0.9674 & 0.9660 \\
\hline & $(0.000)$ & $(0.000)$ & $(0.000)$ & $(0.000)$ & $(0.000)$ \\
\hline \multirow{2}{*}{ Exchange Rates } & 0.9874 & 0.9027 & -0.1972 & 0.8954 & 0.9896 \\
\hline & $(0.000)$ & $(0.000)$ & $(0.598)$ & $(0.000)$ & $(0.000)$ \\
\hline France & FR/\$ & FR/£ & FR/¥ & FR/CHF & FR/DM \\
\hline \multirow{2}{*}{ Stock Returns } & 0.9899 & 0.9907 & 0.9893 & 0.9902 & 0.9876 \\
\hline & $(0.000)$ & $(0.000)$ & $(0.000)$ & $(0.000)$ & $(0.000)$ \\
\hline \multirow{2}{*}{ Exchange Rates } & -0.3573 & 0.9926 & 0.9804 & 0.9811 & 0.9507 \\
\hline & $(0.104)$ & $(0.000)$ & $(0.000)$ & $(0.000)$ & $(0.000)$ \\
\hline Germany & DM/\$ & $\mathbf{D M} / £$ & DM/¥ & DM/CHF & \\
\hline \multirow{2}{*}{ Stock Returns } & 0.9931 & 0.9843 & 0.9895 & 0.9859 & \\
\hline & $(0.000)$ & $(0.000)$ & $(0.000)$ & $(0.000)$ & \\
\hline \multirow{2}{*}{ Exchange Rates } & -0.4816 & 0.9930 & 0.9846 & 0.9767 & \\
\hline & $(0.289)$ & $(0.000)$ & $(0.000)$ & $(0.000)$ & \\
\hline Italy & Lira/\$ & Lira/£ & Lira/¥ & Lira/CHF & Lira/DM \\
\hline \multirow{2}{*}{ Stock Returns } & 0.9613 & 0.9355 & 0.9634 & 0.9406 & 0.9351 \\
\hline & $(0.000)$ & $(0.000)$ & $(0.000)$ & $(0.000)$ & $(0.000)$ \\
\hline \multirow{2}{*}{ Exchange Rates } & 0.9945 & 0.9390 & 0.9983 & 0.9829 & 0.9749 \\
\hline & $(0.000)$ & $(0.000)$ & $(0.000)$ & $(0.000)$ & $(0.000)$ \\
\hline Japan & $¥ / \$$ & $¥ / £$ & $¥ / \mathrm{CHF}$ & ¥/DM & \\
\hline \multirow{2}{*}{ Stock Returns } & 0.9874 & 0.9856 & 0.9870 & 0.9861 & \\
\hline & $(0.000)$ & $(0.000)$ & $(0.000)$ & $(0.000)$ & \\
\hline \multirow{2}{*}{ Exchange Rates } & 0.9405 & 0.9097 & 0.5479 & 0.9867 & \\
\hline & $(0.000)$ & $(0.000)$ & $(0.000)$ & $(0.000)$ & \\
\hline UK & $\mathfrak{£} / \$$ & $\mathfrak{£ / ¥}$ & $£ / C H F$ & $\mathfrak{f} / \mathbf{D M}$ & \\
\hline \multirow{2}{*}{ Stock Returns } & 0.9947 & 0.9937 & 0.9948 & 0.9943 & \\
\hline & $(0.000)$ & $(0.000)$ & $(0.000)$ & $(0.000)$ & \\
\hline \multirow{2}{*}{ Exchange Rates } & 0.9934 & 0.9102 & 0.9871 & 0.9924 & \\
\hline & $(0.000)$ & $(0.000)$ & $(0.000)$ & $(0.000)$ & \\
\hline $\mathbf{U S}$ & $\$ / £$ & 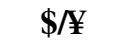 & \$/CHF & \$/DM & \\
\hline \multirow{2}{*}{ Stock Returns } & 0.9372 & 0.9399 & 0.9615 & 0.9475 & \\
\hline & $(0.000)$ & $(0.000)$ & $(0.000)$ & $(0.000)$ & \\
\hline \multirow{2}{*}{ Exchange Rates } & 0.9964 & 0.9554 & 0.7299 & -0.4999 & \\
\hline & $(0.000)$ & $(0.000)$ & $(0.000)$ & $(0.472)$ & \\
\hline
\end{tabular}


Table 16 EGARCH RESULTS ASYMMETRIC SPILLOVERS 1999-2001

\begin{tabular}{|c|c|c|c|c|c|}
\hline Canada & $\mathrm{C} \$ / \$$ & $\mathrm{C} \$ / ¥$ & $\mathrm{C} \$ \mathrm{CHF}$ & $\mathrm{C} \$ / £$ & $\mathrm{C} \$ / €$ \\
\hline \multirow[t]{2}{*}{ Stock Returns } & 0.9385 & 0.9398 & 0.9413 & 0.9365 & 0.9682 \\
\hline & $(0.000)$ & $(0.000)$ & $(0.000)$ & $(0.000)$ & $(0.000)$ \\
\hline \multirow[t]{2}{*}{ Exchange Rates } & 0.3974 & 0.9778 & 0.9169 & -0.6604 & -0.7229 \\
\hline & $(0.285)$ & $(0.000)$ & $(0.000)$ & $(0.047)$ & $(0.329)$ \\
\hline France & $€ / \$$ & $€ / £$ & $€ / ¥$ & $€ / C H F$ & \\
\hline \multirow[t]{2}{*}{ Stock Returns } & 0.9415 & 0.9437 & 0.9484 & 0.9483 & \\
\hline & $(0.000)$ & $(0.000)$ & $(0.000)$ & $(0.000)$ & \\
\hline \multirow[t]{2}{*}{ Exchange Rates } & -0.8955 & -0.0025 & 0.9047 & 0.9597 & \\
\hline & $(0.000)$ & $(0.994)$ & $(0.000)$ & $(0.000)$ & \\
\hline Germany & $€ / \$$ & $€ / £$ & $€ / ¥$ & $€ / \mathrm{CHF}$ & \\
\hline \multirow[t]{2}{*}{ Stock Returns } & 0.9181 & 0.9084 & 0.9152 & 0.9118 & \\
\hline & $(0.000)$ & $(0.000)$ & $(0.000)$ & $(0.000)$ & \\
\hline \multirow[t]{2}{*}{ Exchange Rates } & -0.8885 & -0.0042 & 0.9204 & 0.9614 & \\
\hline & $(0.000)$ & $(0.990)$ & $(0.000)$ & $(0.000)$ & \\
\hline Italy & $€ / \mathrm{CHF}$ & $€ / ¥$ & $\boldsymbol{€} / £$ & $€ / \$$ & \\
\hline \multirow[t]{2}{*}{ Stock Returns } & 0.9426 & 0.9385 & 0.9375 & 0.9371 & \\
\hline & $(0.000)$ & $(0.000)$ & $(0.000)$ & $(0.000)$ & \\
\hline \multirow[t]{2}{*}{ Exchange Rates } & 0.9608 & 0.9054 & 0.0176 & -0.8917 & \\
\hline & $(0.000)$ & $(0.000)$ & $(0.963)$ & $(0.000)$ & \\
\hline Japan & $¥ / €$ & $¥ / \$$ & $¥ / £$ & $¥ / \mathrm{CHF}$ & \\
\hline \multirow[t]{2}{*}{ Stock Returns } & 0.9325 & 0.9337 & 0.9325 & 0.9391 & \\
\hline & $(0.000)$ & $(0.000)$ & $(0.000)$ & $(0.000)$ & \\
\hline \multirow[t]{2}{*}{ Exchange Rates } & 0.9236 & 0.9795 & 0.9611 & 0.9391 & \\
\hline & $(0.000)$ & $(0.000)$ & $(0.000)$ & $(0.000)$ & \\
\hline UK & $\mathfrak{£} / €$ & $\mathfrak{f} / \mathbf{\$}$ & $\mathfrak{£} / ¥$ & £/CHF & \\
\hline \multirow[t]{2}{*}{ Stock Returns } & 0.9306 & 0.9173 & 0.9214 & 0.9183 & \\
\hline & $(0.000)$ & $(0.000)$ & $(0.000)$ & $(0.000)$ & \\
\hline \multirow[t]{2}{*}{ Exchange Rates } & -0.7294 & -0.7077 & 0.9824 & 0.9439 & \\
\hline & $(0.000)$ & $(0.000)$ & $(0.000)$ & $(0.000)$ & \\
\hline US & $\$ / €$ & $\$ / £$ & $\$ / ¥$ & \$/CHF & \\
\hline \multirow[t]{2}{*}{ Stock Returns } & 0.9662 & -0.7464 & 0.9643 & 0.9698 & \\
\hline & $(0.000)$ & $(0.000)$ & $(0.000)$ & $(0.000)$ & \\
\hline \multirow[t]{2}{*}{ Exchange Rates } & -0.9072 & -0.7464 & 0.9831 & 0.7417 & \\
\hline & $(0.000)$ & $(0.000)$ & $(0.000)$ & $(0.102)$ & \\
\hline
\end{tabular}


Table 17 EGARCH RESULTS ASYMMETRIC SPILLOVERS 2002-2006

\begin{tabular}{|c|c|c|c|c|c|}
\hline Canada & $\mathrm{C} \$ / \$$ & $\mathrm{C} \$ / ¥$ & $\mathrm{C} \$ \mathrm{CHF}$ & $\mathrm{C} \$ / £$ & $\mathrm{C} \$ / €$ \\
\hline \multirow{2}{*}{ Stock Returns } & 0.9658 & 0.9649 & 0.9658 & 0.9651 & 0.9562 \\
\hline & $(0.000)$ & $(0.000)$ & $(0.000)$ & $(0.000)$ & $(0.000)$ \\
\hline \multirow{2}{*}{ Exchange Rates } & 0.9763 & 0.9703 & 0.9570 & 0.9923 & -0.6080 \\
\hline & $(0.000)$ & $(0.000)$ & $(0.000)$ & $(0.000)$ & $(0.002)$ \\
\hline France & $€ / \$$ & $€ / £$ & $€ / ¥$ & $€ / \mathrm{CHF}$ & \\
\hline \multirow{2}{*}{ Stock Returns } & 0.9858 & 0.9844 & 0.9864 & 0.9858 & \\
\hline & $(0.000)$ & $(0.000)$ & $(0.000)$ & $(0.000)$ & \\
\hline \multirow{2}{*}{ Exchange Rates } & 0.9824 & 0.9983 & 0.9946 & 0.9669 & \\
\hline & $(0.000)$ & $(0.000)$ & $(0.000)$ & $(0.000)$ & \\
\hline Germany & $€ / \$$ & $€ / £$ & $€ / ¥$ & $€ / \mathrm{CHF}$ & \\
\hline \multirow{2}{*}{ Stock Returns } & 0.9878 & 0.9871 & 0.9857 & 0.9874 & \\
\hline & $(0.000)$ & $(0.000)$ & $(0.000)$ & $(0.000)$ & \\
\hline \multirow{2}{*}{ Exchange Rates } & 0.9868 & 0.9986 & 0.9947 & 0.9662 & \\
\hline & $(0.000)$ & $(0.000)$ & $(0.000)$ & $(0.000)$ & \\
\hline Italy & $€ / \mathrm{CHF}$ & $€ / ¥$ & $€ / £$ & $€ / \$$ & \\
\hline \multirow{2}{*}{ Stock Returns } & 0.9880 & 0.9878 & 0.9869 & 0.9877 & \\
\hline & $(0.000)$ & $(0.000)$ & $(0.000)$ & $(0.000)$ & \\
\hline \multirow{2}{*}{ Exchange Rates } & 0.9670 & 0.9944 & 0.9975 & 0.9842 & \\
\hline & $(0.000)$ & $(0.000)$ & $(0.000)$ & $(0.000)$ & \\
\hline Japan & $¥ / €$ & $¥ / \$$ & $¥ / £$ & ¥/CHF & \\
\hline \multirow{2}{*}{ Stock Returns } & 0.9750 & 0.9698 & 0.9695 & 0.9699 & \\
\hline & $(0.000)$ & $(0.000)$ & $(0.000)$ & $(0.000)$ & \\
\hline \multirow{2}{*}{ Exchange Rates } & 0.9943 & -0.2654 & 0.0039 & 0.8993 & \\
\hline & $(0.000)$ & $(0.894)$ & $(0.991)$ & $(0.000)$ & \\
\hline UK & $£ / €$ & $\mathfrak{f} / \mathbf{\$}$ & $\mathfrak{£} / \mathbf{z}$ & $£ / C H F$ & \\
\hline \multirow{2}{*}{ Stock Returns } & 0.9872 & 0.9877 & 0.9876 & 0.9876 & \\
\hline & $(0.000)$ & $(0.000)$ & $(0.000)$ & $(0.000)$ & \\
\hline \multirow{2}{*}{ Exchange Rates } & -0.2906 & 0.9963 & 0.9589 & 0.9936 & \\
\hline & $(0.368)$ & $(0.000)$ & $(0.000)$ & $(0.000)$ & \\
\hline US & $\$ / €$ & $\$ / £$ & $\$ / ¥$ & \$/CHF & \\
\hline \multirow{2}{*}{ Stock Returns } & 0.9925 & 0.9924 & 0.9930 & 0.9925 & \\
\hline & $(0.000)$ & $(0.000)$ & $(0.000)$ & $(0.000)$ & \\
\hline \multirow{2}{*}{ Exchange Rates } & 0.9889 & -0.0108 & -0.3173 & 0.9810 & \\
\hline & $(0.000)$ & $(0.970)$ & $(0.687)$ & $(0.000)$ & \\
\hline
\end{tabular}


Table 18 Diagnostic Test on EGARCH models

\begin{tabular}{|c|c|c|c|c|c|}
\hline \multicolumn{6}{|l|}{ Canada } \\
\hline 1996-1998 & $\mathrm{C} \$ / \$$ & $\mathrm{C} \$ / \#$ & C\$/DM & $\mathrm{C} \$ / \mathrm{CHF}$ & $\mathrm{C} \$ / £$ \\
\hline \multicolumn{6}{|l|}{ Stock Returns } \\
\hline JB & 389 & 757 & 395 & 429 & 324 \\
\hline \multirow{2}{*}{$\mathrm{LB}(20)$} & 50.584 & 53.727 & 54.751 & 53.283 & 53.897 \\
\hline & $(0.000)$ & $(0.000)$ & $(0.000)$ & $(0.000)$ & $(0.000)$ \\
\hline \multirow{2}{*}{$\mathrm{LB}^{2}(20)$} & 12.507 & 10.434 & 11.927 & 12.919 & 12.595 \\
\hline & $(0.898)$ & $(0.960)$ & $(0.919)$ & $(0.881)$ & (0.894) \\
\hline \multicolumn{6}{|c|}{ Exchange Rates } \\
\hline JB & 46 & 187 & 74 & 245 & 67 \\
\hline \multirow{2}{*}{$\mathrm{LB}(20)$} & 19.539 & 24.336 & 18.246 & 12.319 & 28.708 \\
\hline & $(0.487)$ & $(0.228)$ & $(0.571)$ & $(0.905)$ & $(0.094)$ \\
\hline \multirow{2}{*}{$\operatorname{LB}^{2}(20)$} & 15.77 & 8.0373 & 36.107 & 12.992 & 13.47 \\
\hline & $(0.731)$ & $(0.992)$ & $(0.015)$ & $(0.878)$ & $(0.856)$ \\
\hline \multicolumn{6}{|l|}{ Cross Products } \\
\hline \multirow{2}{*}{$\mathrm{LB}(20)$} & 17.635 & 29.27 & 18.606 & 14.511 & 16.194 \\
\hline & $(0.611)$ & $(0.083)$ & $(0.548)$ & $(0.804)$ & $(0.705)$ \\
\hline \multirow{2}{*}{$\mathrm{LB}^{2}(20)$} & 14.614 & 49.117 & 20.332 & 11.218 & 2.9102 \\
\hline & $(0.798)$ & $(0.000)^{*}$ & $(0.437)$ & $(0.940)$ & $(1.000)$ \\
\hline 1999-2001 & $\mathrm{C} \$ / \$$ & $\mathrm{C} \$ / \mathbf{z}$ & $\mathrm{C} \$ / \mathrm{CHF}$ & $\mathrm{C} \$ / £$ & $\mathrm{C} \$ / €$ \\
\hline \multicolumn{6}{|l|}{ Stock Returns } \\
\hline JB & 83 & 86 & 73 & 82 & 56 \\
\hline \multirow{2}{*}{$\mathrm{LB}(20)$} & 18.661 & 18.547 & 17.752 & 18.386 & 25.749 \\
\hline & $(0.544)$ & $(0.551)$ & $(0.604)$ & $(0.562)$ & $(0.174)$ \\
\hline \multirow{2}{*}{$\mathrm{LB}^{2}(20)$} & 6.9292 & 7.6807 & 7.5534 & 7.2135 & 7.6796 \\
\hline & $(0.997)$ & (0.994) & $(0.991)$ & $(0.996)$ & $(0.994)$ \\
\hline \multicolumn{6}{|c|}{ Exchange Rates } \\
\hline JB & 18 & 18 & 21 & 16 & 17 \\
\hline \multirow{2}{*}{$\mathrm{LB}(20)$} & 22.689 & 14.777 & 31.638 & 26.505 & 32.342 \\
\hline & (0304) & $(0.789)$ & $(0.047)$ & $(0.150)$ & $(0.040)$ \\
\hline \multirow{2}{*}{$\operatorname{LB}^{2}(20)$} & 44.719 & 12.831 & 15.091 & 17.999 & 25.543 \\
\hline & $(0.001)^{*}$ & $(0.885)$ & $(0.771)$ & $(0.587)$ & $(0.181)$ \\
\hline \multicolumn{6}{|c|}{ Cross Products } \\
\hline \multirow[t]{2}{*}{$\mathrm{LB}(20)$} & 15.066 & 15.896 & 14.089 & 18.742 & 17.966 \\
\hline & $(0.773)$ & $(0.723)$ & $(0.826)$ & $(0.539)$ & $(0.590)$ \\
\hline \multirow{2}{*}{$\mathrm{LB}^{2}(20)$} & 4.1503 & 11.937 & 4.692 & 9.877 & 12.113 \\
\hline & $(1.000)$ & $(0.918)$ & $(1.000)$ & $(0.970)$ & $(0.912)$ \\
\hline & $\mathrm{C} \$ / \$$ & $\mathrm{C} \$ / ¥$ & $\mathrm{C} \$ / \mathrm{CHF}$ & $\mathrm{C} \$ / £$ & $\mathrm{C} \$ / €$ \\
\hline Stock Returns & & & & & \\
\hline JB & 22 & 25 & 28 & 23 & 28 \\
\hline $\mathrm{I} \mathrm{P}(20)$ & 15.884 & 14.465 & 13.859 & 14.316 & 12.92 \\
\hline $\mathrm{LD}(20)$ & $(0.724)$ & $(0.806)$ & $(0.838)$ & $(0.814)$ & $(0.881)$ \\
\hline $\mathrm{IR}^{2}(20)$ & 18.499 & 18.248 & 19.627 & 19.883 & 13.238 \\
\hline $\mathrm{LB}^{2}(2 \mathrm{C})$ & $(0.555)$ & $(0.571)$ & $(0.481)$ & $(0.465)$ & $(0.867)$ \\
\hline Exchange Rate & & & & & \\
\hline JB & 9 & 20 & 7 & 7 & 3 \\
\hline $\operatorname{LD}(20)$ & 16.257 & 49.509 & 77.078 & 20.578 & 14.005 \\
\hline $\mathrm{LB}(20)$ & $(0.701)$ & $(0.000)^{*}$ & $(0.000) *$ & $(0.422)$ & $(0.830)$ \\
\hline $\mathrm{JB}^{2}(20)$ & 28.365 & 16.122 & 18.381 & 27.212 & 59.112 \\
\hline$L D=(20)$ & $(0.101)$ & $(0.709)$ & $(0.562)$ & $(0.129)$ & $(0.000)^{*}$ \\
\hline Cross Product & & & & & \\
\hline $\mathrm{LB}(20)$ & 21.431 & 16.748 & 23.474 & 20.657 & 32.503 \\
\hline & 12.337 & $\begin{array}{l}(0.609) \\
11.382\end{array}$ & $\begin{array}{c}(0.206) \\
6.741\end{array}$ & $\begin{array}{l}0.410) \\
15.677\end{array}$ & $\begin{array}{l}(0.050) \\
28.945\end{array}$ \\
\hline $\mathrm{LB}^{2}(20)$ & $(0.904)$ & $(0.936)$ & $(0.997)$ & $(0.736)$ & $(0.089)$ \\
\hline
\end{tabular}

*LB2(32):53.005(0.011); LB2(9):18.074(0.034); LB(41):64.861(0.010); LB2(9):16.766(0.053) 
Table 19 Diagnostic Test on EGARCH models

\begin{tabular}{|c|c|c|c|c|c|}
\hline \multicolumn{6}{|l|}{ France } \\
\hline 1996-1998 & FR/\$ & FR/£ & FR/\# & FR/CHF & FR/DM \\
\hline Stock Returns & & & & & \\
\hline JB & 11 & 4 & 7 & 10 & 7 \\
\hline $\mathrm{LB}(20)$ & $\begin{array}{l}23.11 \\
(0.283)\end{array}$ & $\begin{array}{l}23.531 \\
(0.263)\end{array}$ & $\begin{array}{l}19.37 \\
(0.498)\end{array}$ & 21.582 & 22.482 \\
\hline & $\begin{array}{l}(0.283) \\
7.9367\end{array}$ & $\begin{array}{l}(0.203) \\
7.8246\end{array}$ & $\begin{array}{l}(0.498) \\
6.7154\end{array}$ & $\begin{array}{l}(0.364) \\
7.6451\end{array}$ & $\begin{array}{l}(0.315) \\
7.8243\end{array}$ \\
\hline $\mathrm{LB}^{2}(20)$ & (0.992) & $(0.993)$ & (0.998) & (0.994) & $(0.993)$ \\
\hline \multicolumn{6}{|l|}{ Exchange Rates } \\
\hline $\mathrm{JB}$ & 19 & 39 & 114 & 44 & 66 \\
\hline $\mathrm{LB}(20)$ & $\begin{array}{l}12.361 \\
(0.903)\end{array}$ & $\begin{array}{l}14.973 \\
(0.778)\end{array}$ & $\begin{array}{c}15.39 \\
(0.754)\end{array}$ & $\begin{array}{l}12.926 \\
(0.881)\end{array}$ & $\begin{array}{c}76.764 \\
(0.000)^{*}\end{array}$ \\
\hline $\mathrm{LB}^{2}(20)$ & $\begin{array}{l}36.008 \\
(0.015)\end{array}$ & $\begin{array}{l}20.254 \\
(0.442)\end{array}$ & $\begin{array}{l}12.692 \\
(0.890)\end{array}$ & $\begin{array}{l}17.608 \\
(0.613)\end{array}$ & $\begin{array}{c}13.205 \\
(0.868)\end{array}$ \\
\hline \multicolumn{6}{|l|}{ Cross Products } \\
\hline $\mathrm{LB}(20)$ & $\begin{array}{l}17.791 \\
(0.601)\end{array}$ & $\begin{array}{l}21.004 \\
(0.397)\end{array}$ & $\begin{array}{l}20.382 \\
(0.434)\end{array}$ & $\begin{array}{l}28.745 \\
(0.093)\end{array}$ & $\begin{array}{l}14.915 \\
(0.781)\end{array}$ \\
\hline $\mathrm{LB}^{2}(20)$ & $\begin{array}{l}23.717 \\
(0.255)\end{array}$ & $\begin{array}{c}30.86 \\
(0.057)\end{array}$ & $\begin{array}{l}10.219 \\
(0.964)\end{array}$ & $\begin{array}{c}22.426 \\
(0.18)\end{array}$ & $\begin{array}{c}46.381 \\
(0.000)^{*}\end{array}$ \\
\hline 1999-2001 & $€ / \$$ & $\boldsymbol{€} / \mathfrak{£}$ & $€ / ¥$ & $€ / C H F$ & \\
\hline $\begin{array}{c}\text { Stock Returns } \\
\text { JB }\end{array}$ & 4 & 7 & 5 & 7 & \\
\hline $\mathrm{LB}(20)$ & $\begin{array}{l}24.666 \\
(0.215)\end{array}$ & $\begin{array}{l}21.273 \\
(0.381)\end{array}$ & $\begin{array}{l}20.502 \\
(0.427)\end{array}$ & $\begin{array}{l}21.265 \\
(0.382)\end{array}$ & \\
\hline $\mathrm{LB}^{2}(20)$ & $\begin{array}{l}29.966 \\
(0.070)\end{array}$ & $\begin{array}{l}30.199 \\
(0.067)\end{array}$ & $\begin{array}{l}28.182 \\
(0.105)\end{array}$ & $\begin{array}{l}25.834 \\
(0.171)\end{array}$ & \\
\hline \multicolumn{6}{|l|}{ Exchange Rates } \\
\hline $\mathrm{JB}$ & 44 & 28 & 26 & 392 & \\
\hline $\mathrm{LB}(20)$ & $\begin{array}{l}37.236 \\
(0.011)\end{array}$ & $\begin{array}{l}30.548 \\
(0.061)\end{array}$ & $\begin{array}{l}21.012 \\
(0.396)\end{array}$ & $\begin{array}{l}21.817 \\
(0.351)\end{array}$ & \\
\hline $\mathrm{LB}^{2}(20)$ & $\begin{array}{c}39.916 \\
(0.005)^{*}\end{array}$ & $\begin{array}{c}39.213 \\
(0.006)^{*}\end{array}$ & $\begin{array}{l}16.808 \\
(0.665)\end{array}$ & $\begin{array}{l}14.392 \\
(0.810)\end{array}$ & \\
\hline \multicolumn{6}{|l|}{ Cross Products } \\
\hline $\mathrm{LB}(20)$ & $\begin{array}{l}32.065 \\
(0.043)\end{array}$ & $\begin{array}{l}28.389 \\
(0.101)\end{array}$ & $\begin{array}{l}16.104 \\
(0.710)\end{array}$ & $\begin{array}{l}19.462 \\
(0.492)\end{array}$ & \\
\hline $\mathrm{LB}^{2}(20)$ & $\begin{array}{l}18.399 \\
(0.561)\end{array}$ & $\begin{array}{c}19.35 \\
(0.499)\end{array}$ & $\begin{array}{l}8.3721 \\
(0.989)\end{array}$ & $\begin{array}{l}4.3363 \\
(1.000)\end{array}$ & \\
\hline 2002-2006 & $€ / \$$ & $€ / £$ & $€ / ¥$ & $€ / C H F$ & \\
\hline \multicolumn{5}{|l|}{ Stock Returns } & \\
\hline $\mathrm{LB}(20)$ & $\begin{array}{l}25.928 \\
(0.168)\end{array}$ & $\begin{array}{l}22.238 \\
(0.328)\end{array}$ & $\begin{array}{c}24.27 \\
(0.231)\end{array}$ & $\begin{array}{l}22.211 \\
(0.329)\end{array}$ & \\
\hline $\mathrm{LB}^{2}(20)$ & $\begin{array}{c}22.69 \\
(0.304)\end{array}$ & $\begin{array}{l}20.096 \\
(0.452)\end{array}$ & $\begin{array}{l}17.824 \\
(0.599)\end{array}$ & $\begin{array}{c}18 \\
(0.616)\end{array}$ & \\
\hline \multicolumn{6}{|l|}{ Exchange Rates } \\
\hline JB & 15 & 52 & 133 & 95 & \\
\hline $\mathrm{LB}(20)$ & $\begin{array}{l}31.227 \\
(0.052)\end{array}$ & $\begin{array}{l}22.607 \\
(0.308)\end{array}$ & $\begin{array}{l}31.314 \\
(0.051)\end{array}$ & $\begin{array}{l}15.604 \\
(0.741)\end{array}$ & \\
\hline $\mathrm{LB}^{2}(20)$ & $\begin{array}{l}20.226 \\
(0.444)\end{array}$ & $\begin{array}{l}23.067 \\
(0.286)\end{array}$ & $\begin{array}{l}13.627 \\
(0.849)\end{array}$ & $\begin{array}{l}12.875 \\
(0.883)\end{array}$ & \\
\hline \multicolumn{6}{|l|}{ Cross Products } \\
\hline $\mathrm{LB}(20)$ & $\begin{array}{c}56.758 \\
(0.000)^{*}\end{array}$ & $\begin{array}{l}33.204 \\
(0.032)\end{array}$ & $\begin{array}{l}35.872 \\
(0.016)\end{array}$ & $\begin{array}{l}26.591 \\
(0.147)\end{array}$ & \\
\hline $\mathrm{LB}^{2}(20)$ & $\begin{array}{c}36.13 \\
(0.015)\end{array}$ & $\begin{array}{c}56.568 \\
(0.000)^{*}\end{array}$ & $\begin{array}{l}18.915 \\
(0.527)\end{array}$ & $\begin{array}{l}10.732 \\
(0.953)\end{array}$ & \\
\hline
\end{tabular}

*LB2(29):48.588(0.013); LB2(24):42.949(0.010), LB²(22):39.664(0.012); LB(13):27.359(0.011), LB2(20):20.027(0.067) 
Table 20 Diagnostic Test on EGARCH models

\begin{tabular}{|c|c|c|c|c|}
\hline Germany & & & & \\
\hline 1996-1998 & DM/\$ & DM/£ & DM/¥ & DM/CHF \\
\hline \multicolumn{5}{|c|}{ Stock Returns } \\
\hline JB & 14 & 10 & 16 & 15 \\
\hline \multirow{2}{*}{$\mathrm{LB}(20)$} & 20.324 & 18.855 & 19.441 & 17.805 \\
\hline & $(0.438)$ & $(0.531)$ & $(0.493)$ & $(0.600)$ \\
\hline \multirow{2}{*}{$\mathrm{LB}^{2}(20)$} & 17.356 & 14.312 & 14.403 & 10.094 \\
\hline & $(0.630)$ & $(0.814)$ & $(0.809)$ & $(0.966)$ \\
\hline \multicolumn{5}{|c|}{ Exchange Rates } \\
\hline JB & 45 & 32 & 122 & 78 \\
\hline \multirow{2}{*}{$\mathrm{LB}(20)$} & 15.335 & 15.316 & 18.458 & 9.9396 \\
\hline & $(0.757)$ & $(0.758)$ & $(0.557)$ & $(0.969)$ \\
\hline \multirow{2}{*}{$\mathrm{LB}^{2}(20)$} & 15.131 & 16.535 & 10.94 & 7.8623 \\
\hline & $(0.769)$ & $(0.683)$ & $(0.948)$ & $(0.993)$ \\
\hline \multicolumn{5}{|c|}{ Cross Products } \\
\hline \multirow{2}{*}{$\mathrm{LB}(20)$} & 17.878 & 16.525 & 18.333 & 24.856 \\
\hline & $(0.595)$ & $(0.684)$ & $(0.565)$ & $(0.207)$ \\
\hline \multirow{2}{*}{$\mathrm{LB}^{2}(20)$} & 8.362 & 42.49 & 4.6912 & 32.65 \\
\hline & $(0.989)$ & $(0.000)^{*}$ & $(1.000)$ & $(0.037)$ \\
\hline 1999-2001 & $€ / \$$ & 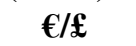 & $€ / ¥$ & $€ / C H F$ \\
\hline \multicolumn{5}{|c|}{ Stock Returns } \\
\hline $\mathrm{JB}$ & 25 & 7 & 9 & 4 \\
\hline \multirow{2}{*}{$\mathrm{LB}(20)$} & 26.326 & 24.048 & 23.657 & 23.181 \\
\hline & $(0.155)$ & $(0.240)$ & $(0.258)$ & $(0.280)$ \\
\hline \multirow{2}{*}{$\mathrm{LB}^{2}(20)$} & 14.727 & 22.581 & 21.721 & 24.475 \\
\hline & $(0.792)$ & $(0.310)$ & $(0.356)$ & $(0.222)$ \\
\hline \multicolumn{5}{|c|}{ Exchange Rates } \\
\hline JB & 43 & 28 & 30 & 386 \\
\hline \multirow{2}{*}{$\mathrm{LB}(20)$} & 36.744 & 30.946 & 21.015 & 22.57 \\
\hline & $(0.013)$ & $(0.056)$ & $(0.936)$ & $(0.310)$ \\
\hline \multirow{2}{*}{$\mathrm{LB}^{2}(20)$} & 35.205 & 35.908 & 16.443 & 16.11 \\
\hline & $(0.019)$ & $(0.016)$ & $(0.689)$ & $(0.710)$ \\
\hline \multicolumn{5}{|c|}{ Cross Products } \\
\hline \multirow{2}{*}{$\mathrm{LB}(20)$} & 29.798 & 28.851 & 7.9922 & 12.198 \\
\hline & $(0.073)$ & $(0.091)$ & $(0.967)$ & $(0.909)$ \\
\hline \multirow{2}{*}{$\mathrm{LB}^{2}(20)$} & 46.009 & 44.686 & 59.215 & 4.1369 \\
\hline & $(0.001)^{*}$ & $(0.000)^{*}$ & $(0.000)$ & $(1.000)$ \\
\hline 2002-2006 & $€ / \$$ & $€ / £$ & $€ / ¥$ & $€ / C H F$ \\
\hline \multicolumn{5}{|c|}{ Stock Returns } \\
\hline JB & 13 & 19 & 13 & 9 \\
\hline $\mathrm{I} R(20)$ & 21.871 & 18.607 & 21.222 & 18.232 \\
\hline $\mathrm{LB}(20)$ & $(0.348)$ & $(0.547)$ & $(0.384)$ & $(0.572)$ \\
\hline $\mathrm{I} \mathrm{R} 2(\mathrm{O})$ & 14.605 & 10.43 & 10.754 & 13.172 \\
\hline $\mathrm{LB}^{2}(20)$ & $(0.799)$ & $(0.960)$ & $(0.952)$ & $(0.870)$ \\
\hline Exchange Rat & & & & \\
\hline JB & 11 & 48 & 143 & 104 \\
\hline $\mathrm{IP}(20)$ & 27.739 & 22.121 & 32.216 & 16.027 \\
\hline $\mathrm{LB}(20)$ & $(0.116)$ & $(0.334)$ & $(0.041)$ & $(0.715)$ \\
\hline I P2(20) & 24.533 & 22.368 & 11.979 & 13.763 \\
\hline $\mathrm{LB}^{2}(20)$ & $(0.220)$ & $(0.321)$ & $(0.917)$ & $(0.842)$ \\
\hline Cross Produc & & & & \\
\hline $\mathrm{I} B(20)$ & 50.826 & 35.423 & 28.179 & 29.039 \\
\hline $\mathrm{LB}(20)$ & $(0.000)^{*}$ & $(0.018)$ & $(0.105)$ & $(0.087)$ \\
\hline I D D (20) & 42.541 & 19.792 & 25.965 & 13.963 \\
\hline $\mathrm{LB}^{2}(20)$ & $(0.002)^{*}$ & $(0.471)$ & $(0.167)$ & $(0.832)$ \\
\hline
\end{tabular}


Table 21 Diagnostic Test on EGARCH models

\begin{tabular}{|c|c|c|c|c|c|}
\hline \multicolumn{6}{|l|}{ Italy } \\
\hline $\begin{array}{c}\text { 1996-1998 } \\
\text { Stock Returns }\end{array}$ & LIRA/CHF & LIRA/¥ & LIRA/DM & LIRA/£ & LIRA/\$ \\
\hline JB & 15 & 31 & 20 & 26 & 43 \\
\hline $\mathrm{LB}(20)$ & $\begin{array}{l}23.848 \\
(0.249)\end{array}$ & $\begin{array}{l}23.466 \\
(0.266)\end{array}$ & $\begin{array}{c}29.863 \\
(0.0072)\end{array}$ & $\begin{array}{l}23.745 \\
(0.254)\end{array}$ & $\begin{array}{l}22.535 \\
(0.312)\end{array}$ \\
\hline $\mathrm{LB}^{2}(20)$ & $\begin{array}{l}19.997 \\
(0.458)\end{array}$ & $\begin{array}{l}16.592 \\
(0.679)\end{array}$ & $\begin{array}{l}17.702 \\
(0.607)\end{array}$ & $\begin{array}{l}17.048 \\
(0.650)\end{array}$ & $\begin{array}{l}14.667 \\
(0.795)\end{array}$ \\
\hline Exchange Rates & & & & & \\
\hline JB & 46 & 137 & 106 & 21 & 38 \\
\hline $\mathrm{LB}(20)$ & $\begin{array}{l}11.204 \\
(0.941)\end{array}$ & $\begin{array}{l}15.531 \\
(0.745)\end{array}$ & $\begin{array}{l}31.792 \\
(0.046)\end{array}$ & $\begin{array}{l}19.333 \\
(0.500)\end{array}$ & $\begin{array}{l}13.682 \\
(0.846)\end{array}$ \\
\hline $\mathrm{LB}^{2}(20)$ & $\begin{array}{l}19.695 \\
(0.477)\end{array}$ & $\begin{array}{c}6.613 \\
(0.989)\end{array}$ & $\begin{array}{l}18.171 \\
(0.576)\end{array}$ & $\begin{array}{l}19.550 \\
(0.486)\end{array}$ & $\begin{array}{l}37.219 \\
(0.011)\end{array}$ \\
\hline Cross Products & & & & & \\
\hline $\mathrm{LB}(20)$ & $\begin{array}{l}24.965 \\
(0.203)\end{array}$ & $\begin{array}{l}10.677 \\
(0.954)\end{array}$ & $\begin{array}{l}29.421 \\
(0.080)\end{array}$ & $\begin{array}{c}29.74 \\
(0.074)\end{array}$ & $\begin{array}{l}12.336 \\
(0.904)\end{array}$ \\
\hline $\mathrm{LB}^{2}(20)$ & $\begin{array}{l}8.8149 \\
(0.985)\end{array}$ & $\begin{array}{l}0.5807 \\
(1.000)\end{array}$ & $\begin{array}{l}8.7528 \\
(0.986)\end{array}$ & $\begin{array}{l}4.9999 \\
(1.000)\end{array}$ & $\begin{array}{l}0.6451 \\
(1.000)\end{array}$ \\
\hline 1999-2001 & $€ / \mathrm{CHF}$ & $€ / ¥$ & $€ / £$ & $€ / \$$ & \\
\hline Stock Returns & & & & & \\
\hline JB & 6 & 9 & 6 & 5 & \\
\hline $\mathrm{LB}(20)$ & $\begin{array}{c}27 \\
(0.142)\end{array}$ & $\begin{array}{l}23.386 \\
(0.270)\end{array}$ & $\begin{array}{l}23.145 \\
(0.282)\end{array}$ & $\begin{array}{l}23.009 \\
(0.288)\end{array}$ & \\
\hline $\mathrm{LB}^{2}(20)$ & $\begin{array}{l}16.578 \\
(0.680)\end{array}$ & $\begin{array}{l}18.114 \\
(0.580)\end{array}$ & $\begin{array}{l}16.437 \\
(0.689)\end{array}$ & $\begin{array}{l}19.109 \\
(0.515)\end{array}$ & \\
\hline Exchange Rates & & & & & \\
\hline JB & 411 & 31 & 28 & 48 & \\
\hline $\mathrm{LB}(20)$ & $\begin{array}{l}22.291 \\
(0.325)\end{array}$ & $\begin{array}{l}20.469 \\
(0.429)\end{array}$ & $\begin{array}{l}28.594 \\
(0.096)\end{array}$ & $\begin{array}{l}30.995 \\
(0.055)\end{array}$ & \\
\hline $\mathrm{LB}^{2}(20)$ & $\begin{array}{l}15.365 \\
(0.755)\end{array}$ & $\begin{array}{l}16.068 \\
(0.712)\end{array}$ & $\begin{array}{c}40.263 \\
(0.005)^{*}\end{array}$ & $\begin{array}{c}41.967 \\
(0.003)^{*}\end{array}$ & \\
\hline Cross Products & $€ / \mathrm{CHF}$ & $€ / ¥$ & $€ / £$ & $€ / \$$ & \\
\hline $\mathrm{LB}(20)$ & $\begin{array}{l}23.862 \\
(0.248)\end{array}$ & $\begin{array}{c}13.011 \\
(0.877)\end{array}$ & $\begin{array}{l}20.214 \\
(0.445)\end{array}$ & $\begin{array}{l}29.864 \\
(0.072)\end{array}$ & \\
\hline $\mathrm{LB}^{2}(20)$ & $\begin{array}{l}10.566 \\
(0.957)\end{array}$ & $\begin{array}{l}23.052 \\
(0.286)\end{array}$ & $\begin{array}{c}42.596 \\
(0.000)^{*}\end{array}$ & $\begin{array}{l}23.923 \\
(0246)\end{array}$ & \\
\hline $\begin{array}{c}\text { 2002-2006 } \\
\text { Stock Returns }\end{array}$ & $€ / \mathrm{CHF}$ & $€ / ¥$ & 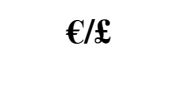 & $€ / \$$ & \\
\hline JB & 43 & 86 & 85 & 58 & \\
\hline $\mathrm{LB}(20)$ & $\begin{array}{c}16.12 \\
(0.709)\end{array}$ & $\begin{array}{l}18.992 \\
(0.522)\end{array}$ & $\begin{array}{l}17.646 \\
(0.611)\end{array}$ & $\begin{array}{l}16.745 \\
(0.669)\end{array}$ & \\
\hline $\mathrm{LB}^{2}(20)$ & $\begin{array}{l}10.368 \\
(0.961)\end{array}$ & $\begin{array}{l}7.4098 \\
(0.995)\end{array}$ & $\begin{array}{l}9.1597 \\
(0.981)\end{array}$ & $\begin{array}{l}8.4719 \\
(0.988)\end{array}$ & \\
\hline Exchange Rates & & & & & \\
\hline $\mathrm{JB}$ & 93 & 136 & 51 & 11 & \\
\hline $\operatorname{LB}(20)$ & $\begin{array}{l}17.629 \\
(0.612)\end{array}$ & $\begin{array}{l}31.613 \\
(0.048)\end{array}$ & $\begin{array}{l}21.434 \\
(0.372)\end{array}$ & $\begin{array}{l}28.688 \\
(0.094)\end{array}$ & \\
\hline $\mathrm{LB}^{2}(20)$ & $\begin{array}{c}12.27 \\
(0.906)\end{array}$ & $\begin{array}{l}13.515 \\
(0.854)\end{array}$ & $\begin{array}{l}20.009 \\
(0.457)\end{array}$ & $\begin{array}{l}20.979 \\
(0.398)\end{array}$ & \\
\hline Cross Products & €/CHF & $€ / ¥$ & $€ / £$ & $€ / \$$ & \\
\hline $\mathrm{LB}(20)$ & $\begin{array}{l}21.918 \\
(0.345)\end{array}$ & $\begin{array}{l}34.941 \\
(0.020)\end{array}$ & $\begin{array}{l}19.785 \\
(0.471)\end{array}$ & $\begin{array}{c}48.811 \\
(0.000)^{*}\end{array}$ & \\
\hline $\mathrm{LB}^{2}(20)$ & $\begin{array}{l}16.934 \\
(0.657)\end{array}$ & $\begin{array}{l}15.265 \\
(0.761)\end{array}$ & $\begin{array}{l}11.048 \\
(0.945)\end{array}$ & $\begin{array}{c}40.239 \\
(0.000)^{*}\end{array}$ & \\
\hline
\end{tabular}


Table 22 Diagnostic Test on EGARCH models

\begin{tabular}{|c|c|c|c|c|}
\hline Japan & & & & \\
\hline 1996-1998 & $¥ / \$$ & $¥ / £$ & $¥ / \mathrm{CHF}$ & ¥/DM \\
\hline \multicolumn{5}{|l|}{ Stock Returns } \\
\hline $\mathrm{JB}$ & 19 & 19 & 20 & 18 \\
\hline $\mathrm{LB}(20)$ & $\begin{array}{l}22.284 \\
(0325)\end{array}$ & $\begin{array}{l}21.886 \\
(0.347)\end{array}$ & $\begin{array}{l}22.615 \\
(0.308)\end{array}$ & $\begin{array}{l}21.775 \\
(0.353)\end{array}$ \\
\hline $\mathrm{LB}^{2}(20)$ & $\begin{array}{l}21.559 \\
(0.365)\end{array}$ & $\begin{array}{l}21.049 \\
(0.394)\end{array}$ & $\begin{array}{c}19.74 \\
(0.474)\end{array}$ & $\begin{array}{l}20.219 \\
(0.444)\end{array}$ \\
\hline \multicolumn{5}{|l|}{ Exchange Rates } \\
\hline $\mathrm{JB}$ & 326 & 90 & 62 & 123 \\
\hline $\mathrm{LB}(20)$ & $\begin{array}{l}19.902 \\
(0.464)\end{array}$ & $\begin{array}{l}16.514 \\
(0.684)\end{array}$ & $\begin{array}{l}24.144 \\
(0.236)\end{array}$ & $\begin{array}{l}16.816 \\
(0.665)\end{array}$ \\
\hline $\mathrm{LB}^{2}(20)$ & $\begin{array}{l}7.9373 \\
(0.992)\end{array}$ & $\begin{array}{l}16.626 \\
(0.677)\end{array}$ & $\begin{array}{l}33.145 \\
(0.033)\end{array}$ & $\begin{array}{l}15.829 \\
(0.727)\end{array}$ \\
\hline \multicolumn{5}{|l|}{ Cross Products } \\
\hline $\mathrm{LB}(20)$ & $\begin{array}{l}33.631 \\
(0.029)\end{array}$ & $\begin{array}{l}26.711 \\
(0.144)\end{array}$ & $\begin{array}{l}25.479 \\
(0.184)\end{array}$ & $\begin{array}{c}31.28 \\
(0.052)\end{array}$ \\
\hline $\mathrm{LB}^{2}(20)$ & $\begin{array}{l}21.444 \\
(0.371)\end{array}$ & $\begin{array}{l}36.965 \\
(0.012)\end{array}$ & $\begin{array}{c}56.363 \\
(0.000)^{*}\end{array}$ & $\begin{array}{c}60.027 \\
(0.000)^{*}\end{array}$ \\
\hline \multicolumn{5}{|l|}{ Stock Returns } \\
\hline JB & 53 & 47 & 49 & 47 \\
\hline $\mathrm{LB}(20)$ & $\begin{array}{l}26.779 \\
(0.142)\end{array}$ & $\begin{array}{l}19.037 \\
(0.519)\end{array}$ & $\begin{array}{l}18.436 \\
(0.559)\end{array}$ & $\begin{array}{l}18.984 \\
(0.523)\end{array}$ \\
\hline $\mathrm{LB}^{2}(20)$ & $\begin{array}{l}16.558 \\
(0.681)\end{array}$ & $\begin{array}{l}16.617 \\
(0.678)\end{array}$ & $\begin{array}{l}16.666 \\
(0.675)\end{array}$ & $\begin{array}{l}16.984 \\
(0.654)\end{array}$ \\
\hline \multicolumn{5}{|l|}{ Exchange Rates } \\
\hline $\mathrm{LB}(20)$ & $\begin{array}{l}19.029 \\
(0.520)\end{array}$ & $\begin{array}{l}23.154 \\
(0.281)\end{array}$ & $\begin{array}{l}13.439 \\
(0.858)\end{array}$ & $\begin{array}{l}18.985 \\
(0.523)\end{array}$ \\
\hline $\mathrm{LB}^{2}(20)$ & $\begin{array}{l}15.846 \\
(0.726)\end{array}$ & $\begin{array}{l}15.85 \\
(0.726)\end{array}$ & $\begin{array}{l}10.015 \\
(0.968)\end{array}$ & $\begin{array}{l}16.984 \\
(0.654)\end{array}$ \\
\hline \multicolumn{5}{|l|}{ Cross Products } \\
\hline $\mathrm{LB}(20)$ & $\begin{array}{l}29.685 \\
(0.075)\end{array}$ & $\begin{array}{l}15.131 \\
(0.769)\end{array}$ & $\begin{array}{l}25.552 \\
(0.181)\end{array}$ & $\begin{array}{l}27.177 \\
(0.130)\end{array}$ \\
\hline $\mathrm{LB}^{2}(20)$ & $\begin{array}{l}8.7263 \\
(0.986)\end{array}$ & $\begin{array}{l}8.3058 \\
(0.990)\end{array}$ & $\begin{array}{l}13.934 \\
(0.834)\end{array}$ & $\begin{array}{l}25.255 \\
(0.192)\end{array}$ \\
\hline 2002-2006 & $¥ / €$ & $¥ / \$$ & $¥ / £$ & $¥ / \mathrm{CHF}$ \\
\hline $\begin{array}{c}\text { Stock Returns } \\
\text { JB }\end{array}$ & 49 & 56 & 58 & 59 \\
\hline $\mathrm{LB}(20)$ & $\begin{array}{r}18.175 \\
(0.576)\end{array}$ & $\begin{array}{l}9.7344 \\
(0.973)\end{array}$ & $\begin{array}{r}10.083 \\
(0.967)\end{array}$ & $\begin{array}{l}9.7879 \\
(0.972)\end{array}$ \\
\hline $\mathrm{LB}^{2}(20)$ & $\begin{array}{l}11.799 \\
(0.923)\end{array}$ & $\begin{array}{l}9.5823 \\
(0.975)\end{array}$ & $\begin{array}{l}8.9081 \\
(0.984)\end{array}$ & $\begin{array}{l}9.1307 \\
(0.981)\end{array}$ \\
\hline Exchange Rates & & & & \\
\hline $\mathrm{JB}$ & 133 & 138 & 210 & 14 \\
\hline $\mathrm{LB}(20)$ & $\begin{array}{l}33.128 \\
(0.033)\end{array}$ & $\begin{array}{c}14.661 \\
(0.0795)\end{array}$ & $\begin{array}{c}38.73 \\
(0.007)^{*}\end{array}$ & $\begin{array}{l}108.15 \\
(0.081)\end{array}$ \\
\hline $\mathrm{LB}^{2}(20)$ & $\begin{array}{l}14.095 \\
(0.826)\end{array}$ & $\begin{array}{l}15.632 \\
(0.739)\end{array}$ & $\begin{array}{l}19.803 \\
(0.470)\end{array}$ & $\begin{array}{l}21.138 \\
(0.389)\end{array}$ \\
\hline Cross Products & & & & \\
\hline $\mathrm{LB}(20)$ & $\begin{array}{l}22.665 \\
(0.306)\end{array}$ & $\begin{array}{l}11.788 \\
(0.923)\end{array}$ & $\begin{array}{l}26.826 \\
(0.140)\end{array}$ & $\begin{array}{c}23.449 \\
(0.267)\end{array}$ \\
\hline $\mathrm{LB}^{2}(20)$ & $\begin{array}{l}6.4011 \\
(0998)\end{array}$ & $\begin{array}{l}4.5495 \\
(1.000)\end{array}$ & $\begin{array}{l}7.5342 \\
(0.995)\end{array}$ & $\begin{array}{l}8.6938 \\
(0.986)\end{array}$ \\
\hline
\end{tabular}

*LB2(17):21.662(0.198); LB2(47):71.638(0.012); LB(19):35.643(0.012) 
Table 23 Diagnostic Test on EGARCH models

\begin{tabular}{|c|c|c|c|c|}
\hline UK & & & & \\
\hline 1996-1998 & $\mathfrak{f} / \$$ & $£ / ¥$ & $£ /$ CHF & £/DM \\
\hline \multicolumn{5}{|l|}{ Stock Returns } \\
\hline JB & 10 & 8 & 6 & 7 \\
\hline $\mathrm{LB}(20)$ & 47.888 & 47.738 & 44.158 & 45.919 \\
\hline & $(0.000) *$ & $(0.000)^{*}$ & $(0.001)^{*}$ & $(0.000)^{*}$ \\
\hline $\mathrm{LB}^{2}(20)$ & $\begin{array}{c}58.783 \\
(0.01)\end{array}$ & $\begin{array}{l}11.777 \\
(0.924)\end{array}$ & $\begin{array}{r}12.154 \\
(0.911)\end{array}$ & $\begin{array}{l}11.437 \\
(0.934)\end{array}$ \\
\hline \multicolumn{5}{|l|}{ Exchange Rates } \\
\hline $\mathrm{JB}$ & 76 & 86 & 95 & 29 \\
\hline $\mathrm{LB}(20)$ & $\begin{array}{c}24.07 \\
(0.239)\end{array}$ & $\begin{array}{l}18.808 \\
(0.534)\end{array}$ & $\begin{array}{l}13.424 \\
(0.858)\end{array}$ & $\begin{array}{l}14.581 \\
(0.800)\end{array}$ \\
\hline $\mathrm{LB}^{2}(20)$ & $\begin{array}{l}17.066 \\
(0.649)\end{array}$ & $\begin{array}{l}17.252 \\
(0.637)\end{array}$ & $\begin{array}{l}23.698 \\
(0.256)\end{array}$ & $\begin{array}{l}18.187 \\
(0.575)\end{array}$ \\
\hline \multicolumn{5}{|l|}{ Cross Products } \\
\hline $\mathrm{LB}(20)$ & $\begin{array}{c}26.58 \\
(0.148)\end{array}$ & $\begin{array}{l}26.051 \\
(0.164)\end{array}$ & $\begin{array}{l}25.491 \\
(0.183)\end{array}$ & $\begin{array}{l}34.752 \\
(0.021)\end{array}$ \\
\hline $\mathrm{LB}^{2}(20)$ & $\begin{array}{l}10.934 \\
(0.948)\end{array}$ & $\begin{array}{l}15.851 \\
(0.726)\end{array}$ & $\begin{array}{l}16.253 \\
(0.701)\end{array}$ & $\begin{array}{l}8.8589 \\
(0.984)\end{array}$ \\
\hline \multicolumn{5}{|l|}{ Stock Returns } \\
\hline JB & 234 & 202 & 207 & 206 \\
\hline $\mathrm{LB}(20)$ & $\begin{array}{l}26.745 \\
(0.143)\end{array}$ & $\begin{array}{l}30.979 \\
(0.055)\end{array}$ & $\begin{array}{l}25.967 \\
(0.167)\end{array}$ & $\begin{array}{l}29.358 \\
(0.081)\end{array}$ \\
\hline $\mathrm{LB}^{2}(20)$ & $\begin{array}{l}5.7629 \\
(0.999)\end{array}$ & $\begin{array}{l}6.2182 \\
(0.999)\end{array}$ & $\begin{array}{l}5.4999 \\
(0.999)\end{array}$ & $\begin{array}{l}6.4189 \\
(0.998)\end{array}$ \\
\hline \multicolumn{5}{|l|}{ Exchange Rates } \\
\hline JB & 8 & 24 & 3223 & 22 \\
\hline $\mathrm{LB}(20)$ & $\begin{array}{c}24.57 \\
(0.218)\end{array}$ & $\begin{array}{l}23.766 \\
(0.253)\end{array}$ & $\begin{array}{l}29.275 \\
(0.082)\end{array}$ & $\begin{array}{l}16.863 \\
(0.662)\end{array}$ \\
\hline $\mathrm{LB}^{2}(20)$ & $\begin{array}{l}36.393 \\
(0.014)\end{array}$ & $\begin{array}{l}32.442 \\
(0.039)\end{array}$ & $\begin{array}{l}30.984 \\
(0.055)\end{array}$ & $\begin{array}{l}9.0466 \\
(0.982)\end{array}$ \\
\hline \multicolumn{5}{|l|}{ Cross Products } \\
\hline $\mathrm{LB}(20)$ & $\begin{array}{l}26.884 \\
(0.139)\end{array}$ & $\begin{array}{l}31.666 \\
(0.047)\end{array}$ & $\begin{array}{l}21.115 \\
(0.390)\end{array}$ & $\begin{array}{l}18.832 \\
(0.533)\end{array}$ \\
\hline $\mathrm{LB}^{2}(20)$ & $\begin{array}{l}7.9564 \\
(0.992)\end{array}$ & $\begin{array}{l}15.329 \\
(0.757)\end{array}$ & $\begin{array}{l}4.0625 \\
(1.000)\end{array}$ & $\begin{array}{l}5.4335 \\
(0.999)\end{array}$ \\
\hline 2002-2006 & $\mathfrak{£} / €$ & $\mathfrak{f} / \$$ & $\mathfrak{f} / ¥$ & $\mathfrak{f} / \mathrm{CHF}$ \\
\hline $\begin{array}{c}\text { Stock Returns } \\
\text { JB }\end{array}$ & 23 & 15 & 18 & 18 \\
\hline $\mathrm{LB}(20)$ & $\begin{array}{l}26.756 \\
(0.142)\end{array}$ & $\begin{array}{l}24.823 \\
(0.208)\end{array}$ & $\begin{array}{l}28.599 \\
(0.096)\end{array}$ & $\begin{array}{l}25.534 \\
(0.182)\end{array}$ \\
\hline $\mathrm{LB}^{2}(20)$ & $\begin{array}{l}21.107 \\
(0.391)\end{array}$ & $\begin{array}{l}25.827 \\
(0.172)\end{array}$ & $\begin{array}{l}20.965 \\
(0.399)\end{array}$ & $\begin{array}{l}20.784 \\
(0.410)\end{array}$ \\
\hline Exchange Rate & & & & \\
\hline $\mathrm{JB}$ & 67 & 41 & 40 & 10 \\
\hline $\mathrm{LB}(20)$ & $\begin{array}{c}24.17 \\
(0.235)\end{array}$ & $\begin{array}{l}23.881 \\
(0.248)\end{array}$ & $\begin{array}{l}14.056 \\
(0.826)\end{array}$ & $\begin{array}{l}24.817 \\
(0.209)\end{array}$ \\
\hline $\mathrm{LB}^{2}(20)$ & $\begin{array}{l}37.431 \\
(0.010)\end{array}$ & $\begin{array}{l}8.4694 \\
(0.988)\end{array}$ & $\begin{array}{l}8.8236 \\
(0.985)\end{array}$ & $\begin{array}{l}11.119 \\
(0.943)\end{array}$ \\
\hline Cross Products & & & & \\
\hline $\mathrm{LB}(20)$ & $\begin{array}{l}15.163 \\
(0.767)\end{array}$ & $\begin{array}{l}21.101 \\
(0.391)\end{array}$ & $\begin{array}{l}26.346 \\
(0.155)\end{array}$ & $\begin{array}{c}17.58657 \\
(0.619)\end{array}$ \\
\hline $\mathrm{LB}^{2}(20)$ & $\begin{array}{l}14.253 \\
(0.817)\end{array}$ & $\begin{array}{l}21.698 \\
(0.357)\end{array}$ & $\begin{array}{c}36.9 \\
(0.012)\end{array}$ & $\begin{array}{c}9.869 \\
(0.994)\end{array}$ \\
\hline
\end{tabular}

*LB(36):58.783(0.01); LB(35):54.471(0.01); LB(26):44.940(0.012);LB(33):54.145(0.012) 
Table 24 Diagnostic Test on EGARCH models

\begin{tabular}{|c|c|c|c|c|}
\hline US & & & & \\
\hline 1996-1998 & $\$ / \mathfrak{£}$ & $\$ / ¥$ & $\$ / \mathrm{CHF}$ & \$/DM \\
\hline \multicolumn{5}{|l|}{ Stock Returns } \\
\hline JB & 65 & 68 & 83 & 59 \\
\hline \multirow[t]{2}{*}{$\mathrm{LB}(20)$} & 21.725 & 23.438 & 19.656 & 19.921 \\
\hline & $(0.356)$ & $(0.268)$ & $(0.480)$ & $(0.463)$ \\
\hline \multirow{2}{*}{$\mathrm{LB}^{2}(20)$} & 11.428 & 13.012 & 11.334 & 14.469 \\
\hline & $(0.934)$ & $(0.877)$ & $(0.937)$ & $(0.806)$ \\
\hline \multicolumn{5}{|c|}{ Exchange Rates } \\
\hline JB & 107 & 343 & 170 & 62 \\
\hline \multirow[t]{2}{*}{$\mathrm{LB}(20)$} & 21.159 & 19.364 & 12.969 & 14.482 \\
\hline & $(0.388)$ & $(0.498)$ & $(0.879)$ & $(0.805)$ \\
\hline \multirow[t]{2}{*}{$\mathrm{LB}^{2}(20)$} & 21.159 & 8.499 & 12.15 & 40.929 \\
\hline & $(0.780)$ & $(0.988)$ & $(0.911)$ & $(0.004)^{*}$ \\
\hline \multicolumn{5}{|c|}{ Cross Products } \\
\hline \multirow[t]{2}{*}{ LB $(20)$} & 21.05 & 20.279 & 12.649 & 24.885 \\
\hline & $(0.394)$ & $(0.441)$ & $(0.892)$ & $(0.206)$ \\
\hline \multirow[t]{2}{*}{$\mathrm{LB}^{2}(20)$} & 4.575 & 2.4032 & 9.0539 & 13.222 \\
\hline & (1.000) & (1.000) & $(0.982)$ & $(0.868)$ \\
\hline 1999-2001 & $\$ / €$ & $\$ / \mathfrak{E}$ & $\$ / ¥$ & $\$ / \mathrm{CHF}$ \\
\hline \multicolumn{5}{|c|}{ Stock Returns } \\
\hline JB & 76 & 81 & 96 & 71 \\
\hline \multirow{2}{*}{$\mathrm{LB}(20)$} & 19.532 & 19.67 & 20.675 & 21.004 \\
\hline & $(0.488)$ & $(0.479)$ & $(0.416)$ & $(0.397)$ \\
\hline \multirow[t]{2}{*}{$\mathrm{LB}^{2}(20)$} & 11.639 & 14.04 & 15.032 & 12.9 \\
\hline & $(0.928)$ & $(0.828)$ & $(0.775)$ & $(0.882)$ \\
\hline \multicolumn{5}{|c|}{ Exchange Rates } \\
\hline JB & 33 & 8 & 53 & 30 \\
\hline \multirow[t]{2}{*}{$\mathrm{LB}(20)$} & 31.226 & 20.37 & 21.298 & 26.351 \\
\hline & $(0.052)$ & $(0.435)$ & $(0.380)$ & $(0.155)$ \\
\hline \multirow[t]{2}{*}{$\mathrm{LB}^{2}(20)$} & 30.887 & 40.126 & 17.674 & 17.541 \\
\hline & $(0.057)$ & $(0.005)^{*}$ & $(0.609)$ & $(0.618)$ \\
\hline \multicolumn{5}{|c|}{ Cross Products } \\
\hline \multirow[t]{2}{*}{ LB(20) } & 31.403 & 35.834 & 31.644 & 51.048 \\
\hline & $(0.050)$ & $(0.016)$ & $(0.047)$ & $(0.123)$ \\
\hline \multirow[t]{2}{*}{$\mathrm{LB}^{2}(20)$} & 21.925 & 17.642 & 70.464 & 27.469 \\
\hline & $(0.345)$ & $(0.611)$ & $(0.000)^{*}$ & $(0.123)$ \\
\hline 2002-2006 & $\$ / €$ & $\$ / £$ & $\$ / ¥$ & $\$ /$ CHF \\
\hline \multicolumn{5}{|l|}{ Stock Returns } \\
\hline JB & 2 & 2 & 2 & 2 \\
\hline $\mathrm{LB}(20)$ & 30.322 & 30.579 & 31.15 & 30.37 \\
\hline & $(0.065)$ & $(0.061)$ & $(0.053)$ & $(0.064)$ \\
\hline $\mathrm{LB}^{2}(20)$ & 37.394 & 36.853 & 33.944 & 37.26 \\
\hline & $(0.01)$ & $(0.012)$ & $(0.027)$ & $(0.011)$ \\
\hline Exchange Rat & & & & \\
\hline JB & 7 & 24 & 165 & 9 \\
\hline $\mathrm{LB}(20)$ & 27.634 & 18.196 & 16.158 & 27.059 \\
\hline & $(0.118)$ & $(0.578)$ & $(0.707)$ & $(0.134)$ \\
\hline $\mathrm{LB}^{2}(20)$ & 26.3 & 79.138 & 15.104 & 22.776 \\
\hline & $(0.156)$ & $(0.000)^{*}$ & $(0.770)$ & $(0.300)$ \\
\hline Cross Produc & & & & \\
\hline $\mathrm{LB}(20)$ & 13.342 & 27.081 & 28.998 & 9.7734 \\
\hline & $(0.862)$ & $(0.133)$ & $(0.088)$ & $(0.972)$ \\
\hline $\mathrm{LB}^{2}(20)$ & 21.508 & 43.29 & 27.996 & 22.778 \\
\hline & $(0.368)$ & $(0.000)^{*}$ & $(0.110)$ & $(0.300)$ \\
\hline
\end{tabular}

*LB2(6)5.044; LB(9):18.533(0.029); ;B(4):7.545(0.01);:LB2(16):7.66(0.958);LB(5):6.097(0.297);

LB(5):1.5454(0.908) 